NBER WORKING PAPER SERIES

THE FINANCIAL IMPACT OF SOCIAL SECURITY BY COHORT UNDER

ALTERNATIVE FINANCING ASSUMPTIONS

Michael J. Boskin

Douglas J. Puffert

Working Paper No. 2225

NATIONAL BUREAU OF ECONOMIC RESEARCH

1050 Massachusetts Avenue

Cambridge, MA 02138

April 1987

We wish to express our thanks to Jessica Primoff for invaluable research assistance, the Stanford University Center for Policy Research for support of this research, and Mary Ross for helpful comments on an earlier draft. The research reported here is part of the NBER's research program in Taxation. Any opinions expressed are those of the authors and not those of the National Bureau of Economic Research. 
NBER Working Paper \#2225

April 1987

\section{The Financial Impact of Social Security by Cohort Under Alternative Financing Assumptions}

\section{ABSTRACT}

This paper analyses the financial impact of Social Security by age cohort under alternative assumptions concerning future financing of Social Security. It examines the Social Security Administration's intermediate IIB and various combinations of optimistic and pessimistic assumptions concerning fertility, mortality, and wage growth. Importantly, it examines the implications of alternative potential resolutions of the long-term financing deficit and scenarios concerning the planned systematic deviation from pay-as-you-go finance in the retirement and disability funds.

The results suggest that the Social Security retirement program offers vastly different returns to households in different circumstances, and especially to different cohorts. Most important, if Social Security does not maintain the large retirement trust fund surplus currently projected for the next 30 years, alternative scenarios for return to pay-as-you-go finance differ dramatically in the taxes, benefits, transfers, and real rates of return that can be offered to different birth cohorts. The implications of cutting taxes, raising benefits or diverting the surplus to other purposes have dramatic impact on the overall financial status of the system, the time pattern of taxes, benefits and surpluses or deficits, and therefore, the treatment of different age cohorts.

Under the intermediate assumptions, the OASDI surplus is projected to grow almost as large as a fraction of GNP as the current ratio of privately held national debt to GNP. For example, if the OASDI surplus is used to raise benefits, and they remained at higher levels thereafter during the height of the baby-boom generation's retirement, the long-run actuarial deficit will zoom from $\$ 500$ billion to over $\$ 3$ trillion. Correspondingly, if benefits increase, financed by the OASDI surplus over the next 30 years, the expected rate of return on lifetime contributions increases for those currently about 40 years old from 1.98 to 2.78 , about a $40 \%$ increase. Correspondingly, if the surplus is dissipated and the subsequent long-run deficit is made up with a tax increase on a pay-as-you-go basis at the time of the projected deficit, the rate of return relative to the intermediate assumptions for those persons now being born will fall by about 158 , and in this case, the overall system finances would move from a long-run actuarial deficit of slightly under one-half percent of taxable payroll to actuarial balance.

Thus, as Social Security is projected to deviate systematically from pay-as-you-go finance, the potential alternative scenarios with respect to accruing the surplus and/or dissipating it in various ways have potentially large intergenerational redistribution effects.

Michael J. Boskin NBER

204 Junipero Serra Boulevard

Stanford, CA 94305
Douglas J. Puffert

NBER

204 Junipero Serra Boulevard Stanford, CA 94305 


\section{Introduction}

For most Americans, anticipated Social Security retirement benefits have a value larger than the total value of their other financial

assets. ${ }^{1}$ Likewise, more than half of the workers in the United States pay more in old Age, Survivors, Disability, and Hospital Insurance (OASDHI) "contributions" than they pay in personal income taxes. Because the program looms so large in the financial picture of so many, it is reasonable to assume that there is a significant demand for an investment evaluation of the "deal" it offers citizens. However, the program is extremely complex, with the expected benefits depending on one's marital status, sex, age-earnings profile, length of career, number of children, and other factors.

In this paper we simplify the analysis by exclusively evaluating the retirement portion of the program. We examine it from the perspectives of the individual household, entire cohorts and aggregate system finances. Our study is partial equilibrium in the sense that we do not tackle the consequences of the program for labor force participation, private saving behavior or funding the federal debt. We compute present values of taxes and benefits using a two percent real discount rate. ${ }^{2}$ We also calculate what individuals receive from Social Security as transfers - the difference between the present values of

1. This value may very well be enhanced by the fact that the benefits are paid out as an inflation adjusted life annuity.

2. See Boskin, Kotlikoff, Puffert and Shoven (1987) for a discussion of the choice of discount rate and sensitivity analyses. 
benefits and taxes. One's transfer is thus the surplus or gain one receives from participating in the system (if the figure is positive). Finally, we compute the internal rate of return offered by the retirement portion of Social Security. That is, we calculate the rate of discount which equates the expected present value of benefits with the expected present value of taxes. Throughout the analysis, we assume the participant bears the burden or effectively pays both the employer and the employee contributions to the system.

The long-run financial status of Social Security is quite uncertain. First, future economic and demographic trends heavily affect revenues and outlays. Second, except under the Social Security Administration's optimistic scenario, the retirement part of the system is projected to be in long-run actuarial deficit: small under the intermediate assumptions; large under the pessimistic ones. Hospital Insurance (HI) is projected to run a large deficit beginning in the 1990s. Finally, the OASDI system is projected to accrue (under the intermediate assumptions) a very large surplus over the next thirty years. This surplus is projected to cumulate to almost $30 \%$ of GNP, close to the current size of the national debt to GNP ratio. This surplus is "designed" to reduce the need for still larger tax increases or benefit reductions during the baby boom generation's retirement. Figure 1 presents estimates of these average annual (not cumulative) surpluses and deficits in Social Security, including and excluding HI over the next 75 years to highlight this projected movement away from pay-as-you-go finance.

We have never been able to accrue a surplus this large in Social Security; the retirement surplus may well be dissipated for other purposes (to bail out HI, fund other programs, raise benefits, cut 
taxes, etc.) These possibilities involve major inter-cohort transfers relative to the intermediate assumptions, as do, of course, the alternative methods of dealing with the long-run deficit (see Boskin (1986)). We analyze these in detail below.

The emphasis of the paper is to calculate the financial terms of Social Security's 01d Age and Survivors Insurance for households from different birth cohorts under alternative possible futures. Our results indicate that the "deal" varies substantially by cohort and that trillions of (real discounted) dollars are at stake for difference cohorts both in the economic and demographic future of the United States and in the use of the projected temporary surplus in the OASI trust fund.

The remainder of the paper is as follows: the next section contains a brief survey of related literature. Section 3 describes our methodology and data. Section 4 presents results using intermediate assumptions for the overall financial status of the system, the situation to be faced by successive ten year birth cohorts (from before 1912 through 1992) and that facing middle income single-earner families born in each of four years: 1945, 1960, 1975 and 1990. Section 5 analyzes the effects of alternative future economic and demographic patterns. In addition to the standard optimistic and pessimistic social Security Administration packages, we also present marginal changes for fertility, mortality and real wage growth. Section 6 estimates the implications of alternative uses of the large surplus which is projected to accrue in OASI's trust fund: what difference it makes, in the aggregate and to specific cohorts if the surplus is used to raise benefits or reduce taxes, or is spent on other programs. 
Section 7 presents a brief conclusion which offers a short summary and repeats some caveats concerning interpretation of the results.

The Appendix presents tables which provide detailed data on the taxes, benefits, transfers and rates of return by cohort and to a "typical" family for the alternative scenarios considered.

\section{Literature Review}

Several studies analyze the long-run financial solvency of Social Security under alternative economic and demographic assumptions. The most important, of course, are the annual Social Security trustees' reports (formally, the Annual Reports of the Board of Trustees of the Old Age and Survivors Insurance and Disability Insurance Trust Funds). They present both short- and long-term actuarial projections of Social Security trust fund finances under alternative assumptions. The reports certainly have valuable information, but these data are presented only as fractions of taxable payroll (except, in one table, as fractions of GNP); dollar figures (whether discounted or not) are not presented for long-term projections. More importantly, the reports do not in fact consider what the state of the retirement (OASI) trust fund might be at the end of the report's 75 year horizon. Rather it presents the simple average, over 75 years, of each year's surplus or deficit (that is, tax receipts minus benefit payments) as a fraction of that year's taxable payroll. The calculation considers neither the increase over time in taxable payroll nor the interest earned on the cumulated trust fund surplus. Thus, the 1986 report's claim that the OASI trust fund is in "close actuarial balance" because the average annual deficit is only 0.29 percent of taxable payroll is based on a fundamental 
misunderstanding of what that figure means. The report presents no sufficient basis for evaluating the long-run financial solvency of old Age and Survivors Insurance. ${ }^{3}$

Boskin's (1986) estimates of the long-run financial solvency of OASI avoids these inadequacies by considering annual flows of dollars and by projecting the actual accumulation and decumulation of the OASI trust fund. He also considers what will happen if the expected cumulative surplus of the next three decades is dissipated (for example, by raising benefits) or if reforms are instituted in retirement age and other features.

Several studies have attempted to estimate the "deal" various households have received or can expect to receive from Social Security's retirement program. The general conclusion is that the early cohorts of retirees had very large rates of return on their taxes and that future retirees, especially well-off ones, are likely to fare poorly, with a rate of return below that available on private assets. Hurd and Shoven (1985) document this pattern of rates of return for various cohorts and earnings levels, but their analysis was made prior to the 1983 amendments and hence does not include consideration of the increased age of eligibility for future retirees or the partial taxation of benefits.

3. In fact, if the report were to present the correct calculation, based on the report's own assumptions and methodology, the resulting figures would be more optimistic under each of the four sets of assumptions used. A comparison of Tables 10 and $F 2$ in the 1986 report shows that taxable payroll is projected to rise at a rate slightly below the assumed interest rate (under each alternative set of assumptions). This means that the earlier positive annual balances should be given greater weight than the later negative annual balances. Thus the long-run actuarial balance should be reported as a little higher. 
Boskin, Avrin and Cone (1983) report the transfer both for aggregate ten year age cohort and for average households in each cohort. They also present estimates of how different cohorts and the system finances as a whole would be affected by various policy changes, such as increases in the retirement age. They conclude that those retiring recently are receiving benefits which are about three times as large as the sum of their employee and employer contributions plus three percent real interest, i.e., about two-thirds of their benefits are transfers. These results are updated to take account of the 1983 amendments in Boskin (1986). The pattern of transfers remains qualitatively similar to that mentioned above, but attention is called to the fact that OASDI is unlikely to be financially solvent over the next 75 years, despite the 1983 amendments. The financial solvency issue is much worse if HI is included. Boskin emphasizes how and when the financial solvency issue is addressed - whether changes occur in the tax rates, benefit formulae, the age of eligibility for full retirement benefits, or the method of financing Social Security.

Pellechio and Goodfellow (1983) examine the net impact of the 1983 amendments on various types of households. Our own analysis of typical households is similar in spirit to theirs.

Boskin, Kotlikoff, Puffert and Shoven (1987) present estimates, ignoring long-run funding issues, for alternative family types and birth cohorts. They conclude that the deal offered by Social Security varies substantially, and has not always been better for poorer persons. The transfers vary by (real discounted) $\$ 200,000$ per family, amounts which dwarf the redistributions debated in alternative income tax reforms. They also note that the marginal linkage between taxes paid and benefits received is quite low (often zero) and thus Social Security ought to be 
viewed as a tax with the concommitant distortions (e.g., in the labor market). They also note that considering previously paid taxes a sunk cost creates a situation in which all but very young workers expect to receive back more in benefits than they expect to pay in taxes for the remainder of their work life; thus most people have a stake in preserving the Social Security system, even though their lifetime transfers are negative.

Finally, Bernheim (1986) notes an Inconsistency in actuarial discounting and maintaining the strong form of the life-cycle hypothesis (an average propensity to consume over the lifetime of one). He argues that simple discounting may be a good approximation for such individuals. Since there is considerable evidence that many individuals refuse annuities (e.g., TIA participants are well known to opt for a certain pension of fixed duration rather than an annuity), and numerous other studies suggest that Iffecycle behavior cannot explain all - - or perhaps most -- saving, the applicability of this to the current paper is questionable. Certainly, the population is heterogeneous, and for some, perhaps simple discounting is appropriate. We discuss these issues in the caveats in the conclusion.

\section{Methodology and Data}

The results which we present here are based on computer simulations of present and future American families covered by the Social Security system. Our main simulation package derives aggregate discounted figures for the taxes paid and benefits received by each of nine successive decadal birth cohorts (a cohort is, for example, all those born from 1943 to 1952). It simultaneously derives figures for annual 
income to and expenditure from the Social Security Administration's retirement (that is, OASI) trust fund over the next 75 years. 4

This simulation begins with earnings records and other data concerning Social Security participants who were surveyed in 1973.5 For subsequent years we estimate participants' earnings based on demographic characteristics, we derive benefits based on legislated benefit formulas, and we determine each participant's year of death through a random process based on mortality tables published by the Social Security Administration. 6

Cohorts born beginning in 1953 are simulated differently. In considering typical male and female wage earners born each year, we derive their expected tax and benefit futures based on mortality probabilities and the proportion that can be expected to marry. We multiply by the number born each year (plus the number born that year who later immigrate as children) who will enter covered employment and thus derive figures for entire cohorts. To derive income and expenditure for the trust fund as a whole we make a further adjustment for taxes paid and benefits received by adult immigrants; the totals for cohorts, however, considers only those covered their entire lives. 7

4. For further information on this simulation, or rather on an earlier version of it, see Boskin, Avrin, and Cone. (1983)

5. The 1975 Social Security Exact Match File merged individual records from the 1973 Current Population Survey with records of covered earnings.

6. Social Security Administration, Actuarial Study No. 92 (1984).

7. It will be noted that our simulation shows the 1943-1952 cohort faring rather worse than its successor, although the general pattern is that succeeding cohorts until about 1960 do progressively worse. The reason for this is that this cohort is the youngest one for which survey data are used, and many in this cohort are not yet married. It is well known that singles fare rather poorly under Social Security, since they have no option to receive a spouse or survivor benefit rather than a benefit 
The discussion is based on a version of our simulation which assumes the tax law effective at the time of the Trustees' Report. Results presented below use the recently enacted income-tax law. Thus, we project small annual deficits for the trust fund in 1986 and 1987 , while the trust fund is actually now running a small surplus. 8

Our simulation goes beyond that of the Social Security Administration in highlighting not only the financial evolution of the trust fund but also the impact on successive cohorts of old Age and Survivors Insurance, both as currently legislated and as it may have to be changed in the future in order to maintain the solvency of the trust fund.

A second simulation ${ }^{9}$ looks at the financial impact of old Age and Survivors Insurance for a variety of typical families. We use this simulation to derive the expected value (in an ex-ante calculation which recognizes the possiblity of death at any age) of a household's social

based on their own earnings.

8. Our calculation is certainly rougher than that undertaken by the actuarial staff of the Social Security Administration. As a result, we generate projections of aggregate taxes and benefits which vary from those of the 1986 Trustee's Report. Between now and 2010 we dervive less in annual and cumulative surpluses (due to deriving less in tax receipts) than what the Trustees' Report suggests is likely. Our figures are close to those of the Trustee's Report in the early 2010's but thereafter until about 2040 we derive greater annual surpluses or lower deficits than those projected in the Trustee's Report. After 2040 we again generate higher annual deficits.

9. More extensive results from this simulation, but based on the income tax law in effect until 1986, are presented in Boskin, Kotlikoff, Puffert and Shoven (1987) and Boskin and Puffert (1987). The former article also contains a more extensive description of our methodology. 
security taxes and benefits, and thus its net transfer and real rate of return.

In the main simulation we rely on Social Security Administration projections for the proportion of Social Security benefits which are recovered for the trust fund through income taxation. These estimates are that this proportion will rise from less than two percent in 1986 to about five percent in the mid-twenty-first century. Because legislated marginal tax rates have been reduced since the Social security Administration made its projections we assume that, from 1988 on, 20 percent less will be collected in taxes on benefits. In 1987, the transition year, we assume that 10 percent less will be collected.

In the second simulation we calculate income taxation for each case, based on the new tax law and data from the Internal Revenue Service about taxable income of the elderly. 10

Both of these simulations are parameterized by economic, demographic, and legal assumptions. The most important economic assumption is future growth of real wages. The chief demographic assumptions are mortality probabilities by age and fertility rates. The legal assumptions are tax rates on payroll and formulae for the calculation of benefits. In the scenarios below we consider the alternative economic and demographic assumptions that the Social Security Administration itself uses for the scenarios in its annual trustees' reports ${ }^{11}$, and we consider fixed multiples of the payroll taxes

10. For details, see Boskin, Kottlikof, Puffert and Shoven (1987). 11. We do not consider alternative assumptions for unemployment, female labor force participation, immigration or real interest rates. 
and the benefits currently legislated.

The present values which we derive assume a real discount rate of two percent. This is the rate which the Social Security Administration assumes (in its intermediate assumption) will be realized on its trust fund. We apply this rate not only to the system's finances, however, but also to participants in Social Security. A subsequent section will discuss arguments that this rate is either too low or too high when applied to individuals, ${ }^{12}$ but we note here one advantage of this figure. When participants can expect a higher rate of return from Social Security than that received by the trust fund, it must be the case that their participation raises the trust fund's unfunded liabilities by the excess of claims on the trust fund over assets. The amount of a cohort's net transfer (discounted benefits minus discounted taxes) is the amount by which the trust fund's unfunded liabilities rise. Conversely, a cohort real rate of return below two percent indicates a decrease in the trust fund's unfunded liabilities.

\section{Results for Intermediate Assumptions}

Table 1 presents the results of our main simulation using the Trustees' Report's intermediate assumptions about future economic and demographic trends. Panel A shows the basic trends, well known by now, that are expected to develop in the finances of the OASI trust fund.

12. In previous work (Boskin, Kotlikoff, Puffert and Shoven (1987)) we and our colleagues argue for a rate of three percent. 
The trust fund will run a substantial surplus over the next 25 years while the baby-boom generation is in its peak earnings years. In the following 25 years (more precisely, in the mid 2020's) when the babyboom generation retires, benefit payments will begin to exceed payrolltax revenues. In the third 25 -year period there will be a still higher proportion of retirees to workers, and annual deficits will equal a fourth of tax receipts, or a fifth of next benefits.

For the whole 75-year period we project a deficit of nearly $\$ 500$ billion in 1986 dollars discounted to 1986 . This is equal to about 0.44 percent of (discounted) taxable payroll. ${ }^{13}$ Thus a rise in the Social Security payroll tax rate of 0.44 percent effective now, or substantially more later, would be needed to close the long-run OASI trust fund deficit if the intermediate assumptions prove to be the case. It is worth noting at this point why we present our figures in discounted terms. First, this enables us to consider the present value of potential futures of the OASI trust fund. This is especially valuablee as we compare scenarios with different time paths of surpluses

13. This is slightly more than the 0.29 percent long-term actuarial deficit presented in the Trustees' Report. We discussed above how the latter figure is not very meaningful, and how a calculation comparable to ours would yield a deficit that is lower in magnitude. A further difference is that our calculation asssumes the new, lower marginal tax rates. Under the old tax law our simulated deficit is about 0.34 percent of taxable payroll. Finally, it should be noted that we make no effort to calculate the future deficit in disability insurance (DI). The Social Security Administration calculates this deficit as averaging 0.15 percent of taxable payroll, or half as large as the OASI deficit. The Social Security Administration total projected OASDI deficit is thus 0.44 percent of taxable payroll. The projected deficit in Hospital Insurance is another 3.5 percent. 
and deficits. Secondly, it obviates the need to give explicit consideration to the interest received (or paid out) by the trust fund on its calculated surplus (or deficit), since we assume that the interest and discount rates are identical. The present (1986) value of the surplus or deficit in 2060 will equal the sum of the present values of annual surpluses and deficits until then. As a corollary, it becomes very simple to compute how taxes or benefits can or must be changesd to bring the trust fund into actuarial balance.

The system finances are also presented in Figure 1, where the discounted surplus both annually and on a cumulative basis for the system are shown. On a cumulative basis the system starts to run a deficit (assuming the surplus accrues and real interest is 2 percent) around 2048, and on an annual basis, around 2025. We present below some hypothetical scenarios of the surplus being dissipated or alternative economic and demographic projections which alter these conclusions substantially.

Table 2 presents results from our simulation of various typical three different levels of earnings, two division of earnings between the family members. The figures include expected present value of taxes, benefits and transfers, and rates of return discounted both to the age when the couples are 25 (for the purposes of comparision) and to 1986 . The discounted present value of transfers (and therefore, taxes and benefits in general) varies markedly within each age cohort for different levels of earnings (reflecting the progressivity of the benefit formulae) and income splits (with respect to the spousal benefit), and to a lesser extent, the ceiling on taxable earnings. For example, persons recently entering the system, born in 1960, have a 
present value of transfers that ranges from a slight positive transfer for low income earners to a substantial negative transfer for highincome earners. The rates of return for taxes paid range from $3.4 \%$ for the low-income single-earner family to 0.48 for the high income twoearner family. The same pattern is repeated within each cohort. The intragenerational redistributions are explored in much greater detail in Boskin, Kotlikoff, Puffert and Shoven (1987).

The financial patterns for successive decadel cohorts born through 1992 are presented in panel b of Table 1. Retiree taxes, net benefits (i.e., net of income taxation), the transfer received by those who live to retire, and the taxes paid by nonsurvivors, together with the real rates of return are presented. As can be seen, even those due to be born in the immediate future are likely to get a slightly positive transfer, computed at a 2 percent real rate of return. Thus, the rates of return which are about 2 percent or more, indicate positive transfers. Were we to use 3 percent, cohorts born after 1933 would be receiving negative transfers.

of course, since there is a long-run actuarial deficit of 0.448 of taxable payroll, amounting in present value to approximately 500 billion dollars, someone will have to pay it. The base case assumes that it is paid by persons born after 1992, whose situation will be correspondingly worse. We present information on how this varies for different rates of return.

Thus, while we will primarily be dealing in the sequel with system totals and aggregates by age cohorts, substantial variation remains within each age cohort, and that variation will vary systematically as we change economic and demographic assumptions and consider alternative scenarios for dissipation of the surplus. In what follows we will 
present only the situation for a typical middle income family with one earner, a group which systematically earns a rate of return very close to 28 cohort by cohort (see Table 2), rather than present a large string of negative numbers for the well-off two-earner couple or a long string of substantial positive numbers for low income one-earner couples. We will focus on this case to see how one-earner middle income couples' situations vary depending on the alternative scenarios. We do this to reduce the system aggregate finances and the aggregate cohort amounts for the cohorts to a per family basis. The heterogeneity that certainly lies behind each of these scenarios should be borne in mind.

\section{Financial Impacts of Alternative Future Economic and Demographic}

The Social Security Administration's intermediate economic and demographic assumptions are perhaps as reasonable as any, but we can be sure that they will not be realized with great accuracy. ${ }^{14}$ It is thus important to consider the impacts of a range of possible futures both on the Social Security system's finances and on participants.

Tables 3 and 4 summarize the effects of using the Social Security Administration's optimistic and pessimistic assumptions for future wage growth, future mortality (and hence, life expectancy), future fertility and various combinations of these parameters. Table 4 shows the wide

14. For an analysis of the inaccuracy of the economic and demographic assumptions used in the past, see United States General Accounting Office (1986). 
variation in results for the financial solvency of the retirement trust fund. The present (1986) value of the trust fund surplus (or deficit) in 2060 ranges from $+\$ 3.4$ trillion to $-\$ 2.6$ trillion, for the combined optimistic and pessimistic assumptions respectively. ${ }^{15}$ We see in the column headed "year annual deficit begins" that only when the optimistic assumptions are combined do tax receipts exceed benefit expenditures in each year through 2060; otherwise current-flow deficits begin between 2014 and 2030. In the next column we see that the cumulative surplus suffices, however, to cover benefit expenditures until 2024 in the most pessimistic scenario and beyond 2060 in several of the optimistic scenarios.

Table 4 compares the rates of return realized by each of the nine decadal birth cohorts under the alternative scenarios. We note first that, for later cohorts, the derived real rates of return vary among scenarios from about one and one-half percent to over three percent.

In order to understand more closely how taxes, benefits, transfers, and rates of return vary by scenario and cohort, let us now consider in detail how each of our economic and demographic assumptions affects both the finances of the Social Security retirement trust fund and the taxes and benefits of those covered by Social Security. The figures discussed below concerning the Social Security Administration's optimistic and pessimistic scenarios are presented in still greater detail in Appendix

15. Undiscounted, but st 111 in 1986 dollars, the respective figures are $+\$ 14.7$ trillion and $-\$ 11.1$ trillion. Subsequent figures are also presented in discounted terms. To remove discounting, multiply by 4.33. 
Tables A.1 and A.2.

The Social Security Administration's intermediate (II-B) assumption for growth in real wages, used in our base case, is that there will be an annual gain of one and one-half percent (with some fluctuation in the very short run). The optimistic assumption considers a gain of two and one-half percent annually, and the pessimistic assumption considers a gain of one percent.

Interestingly, higher wage growth is better both for the system's finances and for participants in the system. An increase in the trust fund's annual surplus (taxes minus benefits) proves consistent with a higher ratio of benefits received to taxes paid for the participants. The reason for this is that increases in taxes, which vary with total wages, precede the increases in benefits to which wage growth leads. The wage index is used in the formula for determining benefits, and so a faster rise in this index provides a higher rate of return for participants. What "balances the books" is a growth in the unfunded liabilities of the retirement trust fund. These liabilities could become quite burdensome if wage growth slows in the future.

We see in Table 3 that variation in wage growth changes taxes and benefits in the same direction, but that taxes change to a greater extent. High wage growth increases the long-run surplus by $\$ 1.37$ trillion, more than offsetting the long-run deficit expected under the base case. Low wage growth deepens the long-run deficit by about $\$ 450$ billion.

Higher (lower) wage growth increases (decreases) both taxes and benefits. It increases (decreases) annual flows of taxes more than benefits but, for a given cohort, increases (decreases) discounted benefits more than discounted taxes. Rates of return for later cohorts 
(also presented in Table 4) vary from about 2.2 percent under intermediate wage growth to about 2.8 percent under high wage growth and 1.9 percent under low wage growth.

In assumptions about mortality, what is "optimistic" for the solvency of the retirement trust fund is "pessimistic" for participants, and vice versa. The trust fund is more solvent when people die sooner and collect less in benefits. Table 3 shows that under the Social Security Administration's high mortality (low life expectancy) assumption the trust fund is better off by $\$ 963$ billion over the 75 -year horizon, but that under the low mortality assumption the system is worse off by $\$ 1.20$ trillion. In Table 4 we see that for later cohorts the rates of return are about 1.9 percent for high mortality and 2.7 percent for low mortality. Higher (lower) mortality reduces (raises) benefits much more than taxes for any cohort, as indeed for the trust fund's annual flow as wel1.

Alternative assumptions about fertility matter only for those cohorts not yet born, which are not presented in our tables. However, because Social Security participants begin paying taxes some forty years before they receive benefits, fertility rates will have a big impact on trust fund finances in the next century. ${ }^{16}$ Indeed, today's low fertility rates are the most widely cited source of probable future problems in Social Security finance. Current fertility rates are about 1.9 children per woman over her child-bearing years. The Social Security

16. The level of immigration, especially of young people, will have an impact for the same reason. We leave this matter for future investigation. 
Administration's intermediate assumption is that this will rise within the next two decades to 2.0 children per woman. The optimistic and pessimistic assumptions are 2.3 and 1.6 respectively. ${ }^{17}$ The results of our simulation, shown in Table 3 , are that high fertility would add $\$ 694$ billion to the trust fund surplus, more than eliminating what is otherwise a deficit, while low fertility would add $\$ 837$ billion to the deficit.

We also derived results for scenarios which combine sets of optimistic and pessimistic assumptions. The assumptions which are optimistic for participants are high wage growth and low mortality (fertility being irrelevant), while the assumptions which are optimistic for trust fund finances are high wage growth, high mortality, and high fertility. In the scenarios which are optimistic and pessimistic for participants, rates of return for later cohorts are about 3.3 percent and 1.6 percent respectively. Comparing Appendix Tables A.9 and A.10, we see that under the combined optimistic assumptions today's young children will pay a little more than twice as much in taxes as they would under the combined pessimistic assumptions, but they will receive nearly four times as much in benefits. The effects on system finances are offsetting and do not differ greatly from the base case.

17. In our simulation we use the Social Security Administration's figures for number of births each calendar year, which are derived from these fertility rates. It should be noted that the fertility rates used by the Social Security Administration refer to "the average number of children who would be born to a woman in her lifetime if she were to experience the birth rates by age observed in, or assumed for, the selected year and if she were to survive the entire child-bearing period." 
Under the combined optimistic and pessimistic assumptions for trust fund finances the differences from the intermediate scenario for longrun surplus are $+\$ 3.88$ trillion and $-\$ 2.07$ trillion (Table 3 ). The present value of taxes differs between these extreme scenarios by a factor of nearly two, while benefits vary by a factor of about 1.3.

Figure 3 shows how the size of the accumulated trust fund varies over the next 75 years for the overall optimistic, intermediate (base case), and pessimistic scenarios. Note that the continuing increase in the trust fund occurs only when the optimistic assumptions occur simultaneously. For any one of the optimistic assumptions alone, interest on the trust fund is eventually insufficient to cover the difference between current benefits and current taxes, and the principal itself is exhausted before 2090 (Table 3, last column).

\section{Financial Impact of Alternative Uses of the Potential Trust Fund}

We noted in the previous section that only under the combined optimistic assumptions for wage growth, mortality, and fertility all together can we hope that the retirement trust fund will take in at least as much each year in taxes as it pays out in benefits. In all other cases an accumulation in the trust fund is vital in order to forestall the time when taxes must be raised or benefits reduced. ${ }^{18}$ Under intermediate

18. Of course, the consumption of the economy as a whole is limited by what is produced, by those still living. Thus, in some sense Social Security benefits must always be funded at the time they are paid. Still, the method of financing Social Security determines who has what claims, and this has important implications both for equity and efficiency. 
assumptions, for example, an annual deficit will begin in 2025 but the accumulated surplus will keep the trust fund solvent until 2048.

Unfortunately it has always proved difficult, for political reasons, to accumulate a trust fund surplus. It is in the interest of each session of Congress, and each administration, to raise benefits (or perhaps to lower taxes, although that has not yet been tried) if possible. Raising benefits conveys transfers to those receiving, or soon to receive, benefits while imposing much of the cost of the action on future generations which do not yet vote. Lowering taxes, similarly, helps a current generation of workers while requiring higher taxes from future generations than would otherwise be necessary.

The situation is now particularly acute for a major demographic reason: in less than 30 years the baby-boom generation will begin to retire. If we do not preserve the accumulation of a trust fund surplus before then, future adjustments in payroll-tax rates or in benefits will have to be much greater than would otherwise be necessary.

Figure 4 depicts the combined (employer and employee) tax rates which would be required each year to fund currently-legislated benefits (given intermediate assumptions) without adding to or drawing upon an accumulated surplus. Until $2025^{19}$ tax rates could be lower than those currently legislated, but thereafter they would rise drastically.

19. The higher tax rate shown for 2022 is a quirk resulting from the way our simulation handles the rise in retirement age, from 66 to 67 , which occurs around that time. We stimulate the change as occuring all at once rather than phased in over several years. 
Conversely, Figure 5 shows the level of benefits which could be funded by each year's tax receipts. This level is presented in the form of a ratio to benefits as provided for under current legislation. We see that benefits could be raised intermittently through 2009 , to a level 30 percent higher than that now legislated, but that thereafter they must either decline or, perhaps more plausible politically, be maintained through increases in payroll tax rates. The tax rates required to finance these increased benefits are depicted in the broken line of Figure 4.

Tables 5 and 6 summarize the financial impacts of several ways of dissipating the trust-fund surplus which is projected to grow over the next 35 to 40 years. "Pay-as-you-go tax rates" considers the scenario in which, beginning in 1990, tax rates are set each year at a level which exactly covers that year's benefit payments. Similarily, "pay-asyou-go benefits" considers, also for 1990 on, the adjustment of benefit levels to match projected tax receipts. The tax rates and benefits levels of these scenarios thus follow the heavy lines depicted in Figures 4 and 5 respectively.

We consider 1990 a plausible starting date for these scenarios because the party that takes office in 1989 will be glad to endear itself to the voters before the 1990 congressional election. By this time the annual surplus in the trust fund will be an inviting target.

The "benefit ratchet" scenarios consider the cases in which benefits rise to their pay-as-you-go peak in 2009 but do not subsequently decline. The first of these scenarios notes the enormous deficit ( $\$ 3.69$ trillion cummulative by 2060) generated when the higher benefit level is not funded with taxes, while the second considers the case of taxes rising, in a pay-as-you-go fashion, to fund the increased 
benefits.

The last two of these scenarios consider what will happen if the surplus which would accumulate over the next forty years is dissipated, or directed to other purposes. Two very plausible possibilities for this are that the surplus could be used to cover some of the massive deficit in Social Security Hospital Insurance which will (absent a major reform) develop within a few years ${ }^{20}$ or that the surplus will, in the face of federal budget deficits, be used to fund other expenditures. The first of these scenarios raises taxes in a pay-as-you-go fashion beginning in 2025, the first year in which current benefit payments exceed current tax receipts. The second of these scenarios reduces benefits in a pay-as-you-go fashion from 2025 on. Thus these scenarios are equivalent to the earlier pay-as-you-go scenarios from 2025 on; they only lack the period in which tax or else benefit levels are more favorable for participants than the levels currently legislated.

The chief result for system finances (Table 5) under all these scenarios - except, of course, the unfunded ratcheting of benefits is that the long run surplus is, by construction, essentially zero. ${ }^{21}$ The story for the successive cohorts, as we see in Table 6 and more extensively in Appendix Tables A.3 through A.8, is that some gain and some lose as a result of these changes.

Thus under pay-as-you-go tax rates, those born until the 1980's

20. In practice, it is more likely that part of OASI's portion of payroll tax will be reallocated to HI. The analysis of OASI finances would then be similar to that of our pay-as-you-go taxrate scenario.

21. A deficlt of $\$ 8$ billion appears for some scenarios due to our simulation showing a slight overall deficit between 1986 and 1989. 
gain; the bulk of their working lives take place before 2025, when tax rates must rise above those currently legislated. The big losers under this scenario are those born in the next century, who will be subject to payroll tax rates of over 13 percent by 2033 (and later over 14 percent), rather than the 10.98 percent currently legislated.

Under pay-as-you-go benefits, those who receive benefits mostly before 2025 gain. Those born from the 1950's on, who collect their benefits after 2025, will do worse than projected under current legislation. Those born today can expect a benefit reduction of 23 percent, for a rate of return of only about 1.5 percent.

With a ratcheting of benefits financed by tax increases, those born until the present decade gain, as their increase in benefits more than offsets the increase in taxes which they pay during part of their working lives. But later cohorts bear the full brunt of these increased tax rates ( 17 percent by 2033, and higher later, compared to 10.98 percent currently legislated) and hence do substantially worse overall.

When the surplus is dissipated, there are no gaining cohorts. But those who pay taxes or collect benefits after 2025 suffer the same losses as in the first two pay-as-you-go scenarios.

\section{Conclusion and Caveats}

The results reported in this research suggest that Social Security's retirement program offers vastly different terms to households in different circumstances and in different cohorts. More importantly, (net of any private intrafamily intergenerational transfers which offset Social Security benefit payments, which we believe to be a modest fraction of the total benefits) if we do not maintain a large 
OASI trust fund, the alternative scenarios for return to pay-as-you-go finance differ dramatically in the taxes, benefits, transfers and real rates of return which can be offered to different birth cohorts.

While it appears that the retirement part of Social Security -but not hospital insurance -- is in sound short-run financial shape and indeed, is projected to accummulate a very substantial surplus over the next 35 to 40 years under intermediate economic and demographic assumptions, various factors could intervene in this relatively rosy short-run scenario. We have attempted to explore some plausible alternatives to the surplus accruing: tax could be cut, benefits increased, or the surplus diverted to other purposes. We have traced their implications for the overall financial status of the system, the time pattern of taxes, benefits and surpluses or deficits, and therefore, the treatment of different age cohorts. Under the intermediate assumptions, the Social Security surplus is projected to become almost as large as today's regular national debt. Obviously, well before this would occur, enormous pressure would be placed on financial markets. Since Hospital Insurance is scheduled to be accruing a substantial deficit well before the surplus peaks, one likely scenario Is that Social Security will "borrow" from the retirement fund to bail out the hospital insurance fund. The retirement surplus also could be a signal to fiscal authorities that additional spending could be financed on other programs, ignoring the simultaneously accruing future liabilities in Social Security. The surplus could be dissipated if the prospective increase in the retirement age is reduced, eliminated, or postponed; and/or if the tax exempt amount is indexed. In all of these situations, the short-run surplus would decrease substantially, and the subsequent long-run deficit would worsen. The exact pattern of tax 
collections and benefit payments might take a variety of forms, but each of these would lead to a much worse deal for retirees in the distant future versus current retirees or those retiring in the near future.

The Social Security retirement system finances are quite sensitive to alternative economic and demographic events. We have presented estimates based upon the Social Security Administration's pessimistic and optimistic packages, but also "unpackaged" them so that we may examine the marginal effect of changing mortality, fertility, and wage growth assumptions. Again, the patterns are revealing. Except in the optimistic package, the discounted value of the Social Security retirement system fund over the next 75 years is negative, and is subject to substantial potential negative shocks for the reasons discussed above.

We have mentioned a number of caveats to our results throughout the paper. First, the new income tax law is certain to change over the time horizon we examine and probably sooner rather than later. Marginal rates may change, Social Security benefits may be taxed fully, some or all of the tax collections from the taxation of Social Security benefits may accrue to general funds to help pay for deficits rather than be credited to Social Security at the time of surplus, etc. Second, we mentioned that the value of Social Security benefits may exceed their expected present value because they are paid as inflation-adjusted joint survivor life annuties. Exactly how to make the adjustments is unclear. Bernheim (1986) argues that a strict adherence to the life-cycle model - at least the aspect of it that implies an average propensity to consume, over one's lifetime, of one - - and imperfections in annuity markets imply that actuarial discounting is inappropriate, and argues 
that simple discounting may be desirable. While we do not hold to this extreme form of the life-cycle model in this paper and there is substantial evidence that if individuals are given the option, they refuse to annuitize their wealth (for example, college professors covered by TIA usually decline annuitization in favor of some years certain in their retirement pension), we do not believe that simple discounting is a sensible alternative to actuarial discounting for the whole population. However, to the extent that a fraction of the population we consider is appropriately considered as pure life-cycle savers and subject to the imperfections in annuity markets, some method of aggregating heterogeneous individuals within cohorts is desirable and perhaps some convex combination of actuarial and simple discounting would be necessary. Simple discounting would alter the benefits and taxes only a few percentage points, given a real discount rate of 2 percent or 3 percent. Again, we would argue that these factors should be applied only to some fraction of the population, not the entire population. For the system totals, such adjustments are unnecessary; indeed, they only make sense for examining the individual cases rather than the system aggregate totals.

Related questions revolve around comparing taxes paid earlier in life and benefits received later in life. Taxes might be paid at a time in life when households are constrained in liquidity; Social Security benefits may be systematically subject to different types of risks than labor earnings or returns from assets. Hence, the taxes may be differentially risky since they are paid on realized earnings during working years relative to Social Security benefits. Again, these issues have been discussed in more detail elsewhere (see Boskin and Shoven (1985)) . 
Thus, some risk adjustment may be necessary. Some have even suggested that the appropriate discount rate should be zero because Social Security benefits really are a safe asset and that is close to the real return on government securities (safe assets) over the longterm (Henry Aaron, Alicia Munnell and others have made this argument). First, adjusting for differences in risk other than mortality risk by adjusting discount rates is inappropriate. Modern finance theory teaches that a charge for risk should be assigned in the appropriate period and the appropriate measure of net adjusted benefits should then be discounted at the rate of time preference. Second, it is unclear whether Social Security benefits or earnings or the returns to other assets are differentially risky. Indeed, it is not just their inherent risk but their covariance with other components of income for households which would determine the nature of the risk charge to be applied. For persons already retired, one would expect that uncertainty would be relatively modest; for those due to retire in the distant future, there is substantial uncertainty regarding the level of such Social Security payments. This stems from the Social Security system's long-term financial solvency problems as well as the desire of many to means-test the program fully. Thus, well-off individuals may wind up getting nothing in the future as the way to deal with the financial solvency problem. We merely point these issues out for the interested reader and refer them to the other papers mentioned for further discussion, but these caveats should be borne in mind in interpreting the results reported here. 


\section{References}

Bernheim, B.D. (1986), "The Economic Effects of Social Security: A Reconciliation of the Theory and the Evidence," Stanford University,
mimeo.

Boskin, M.J. (1986), Too Many Promises: The Uncertain Future of Social Security, Homewood, IL: Dow Jones-Irwin.

Boskin, M.J., M. Avrin and K. Cone (1983), "Modeling Alternative Solutions to the Long-Run Social Security Funding Problem," in M. Feldstein (ed.), Behavioral Simulation Methods in Tax Policy Analysis Chicago: University of Chicago Press.

Boskin, M. J., L.J. Kotlikoff, D.J. Puffert, and J.B. Shoven (1987), "Social Security: A Financial Appraisal Across and Within Generations," Boskin, M.J., L.J. Kotlikoff, and J.B. Shoven (1985), "Personal Security Accounts: A Proposal for Fundamental Social Security Reform, "Policy Paper, Center for Economic Policy Research, Stanford University,
September.

Boskin, M.J., and D.J. Puffert (1987), "Social Security and the American Family," NBER Working Paper No. 2117, January.

Hurd, M.D. and J.B. Shoven (1985), "The Distributional Impact of Social Security," in D.A. Wise (ed.), Pensions, Labor, and Individual Choice, Chicago: University of Chicago Press.

Pellechio, A.J. and G.P. Goodfellow (1983), "Individual Gains and Losses from Social Security Before and After the 1983 Amendments," Cato Journal, Fall.

United States General Accounting office (1986), Social Security: Past Projections and Future Financing Concerns. Washington, DC, March. 


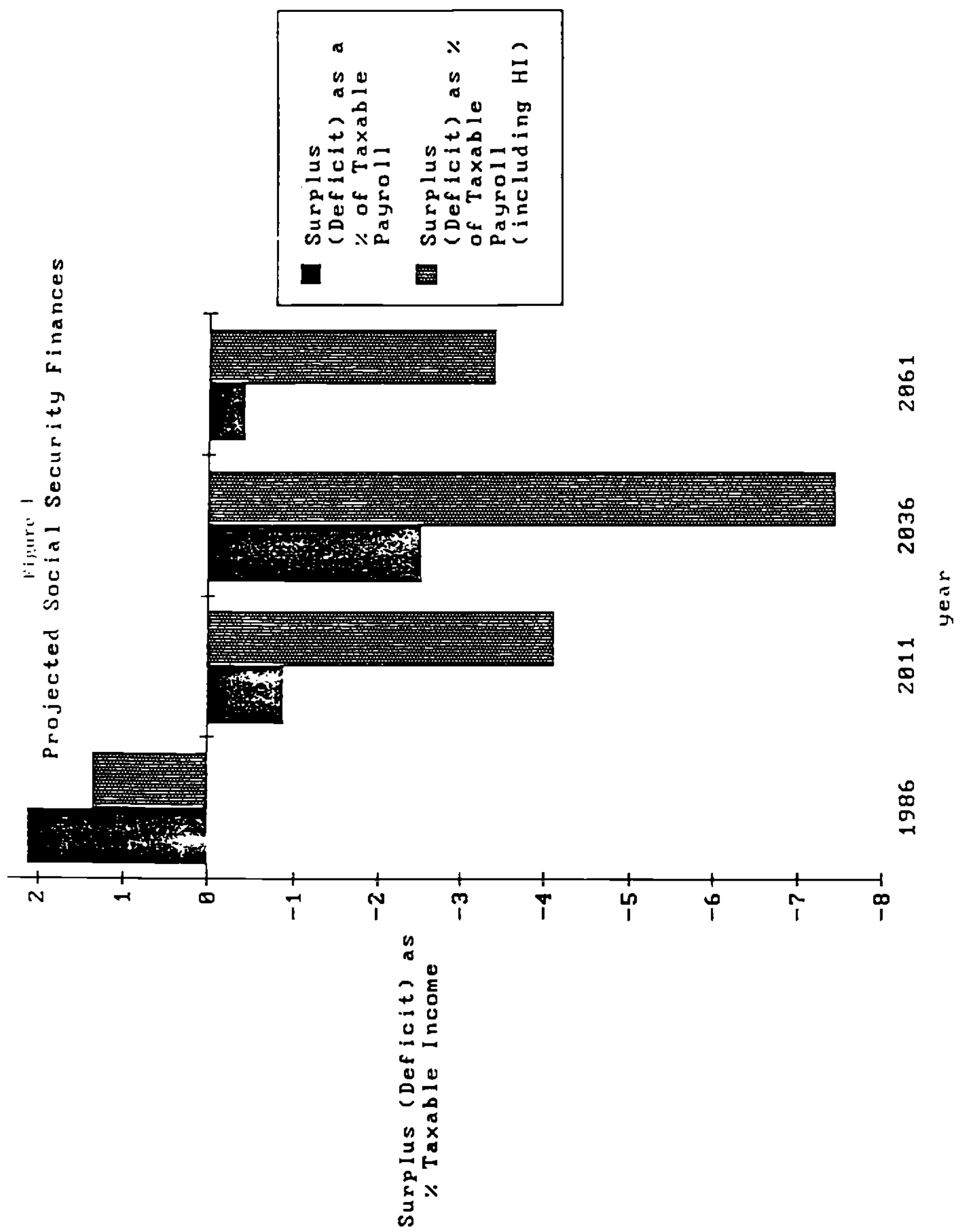




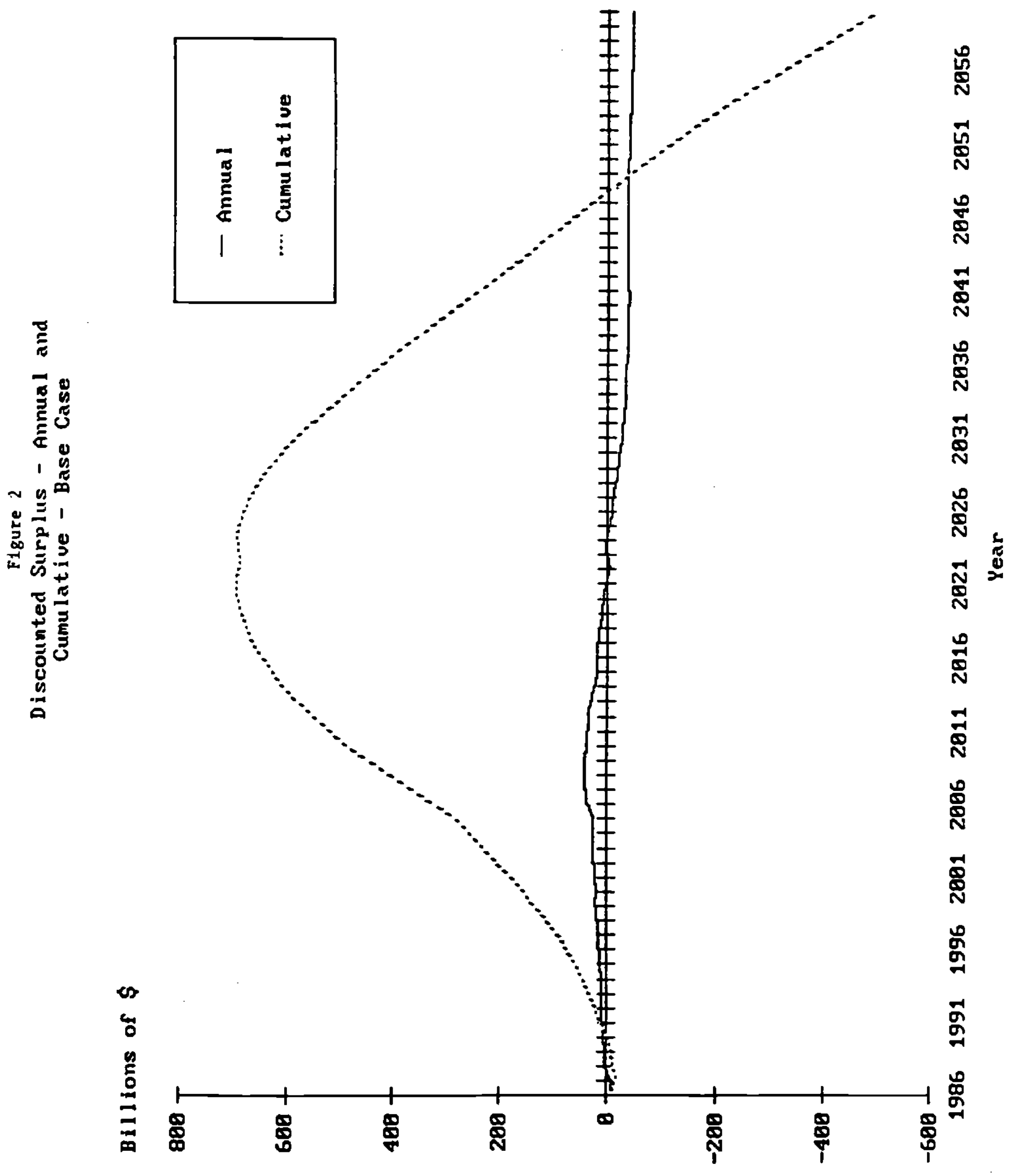




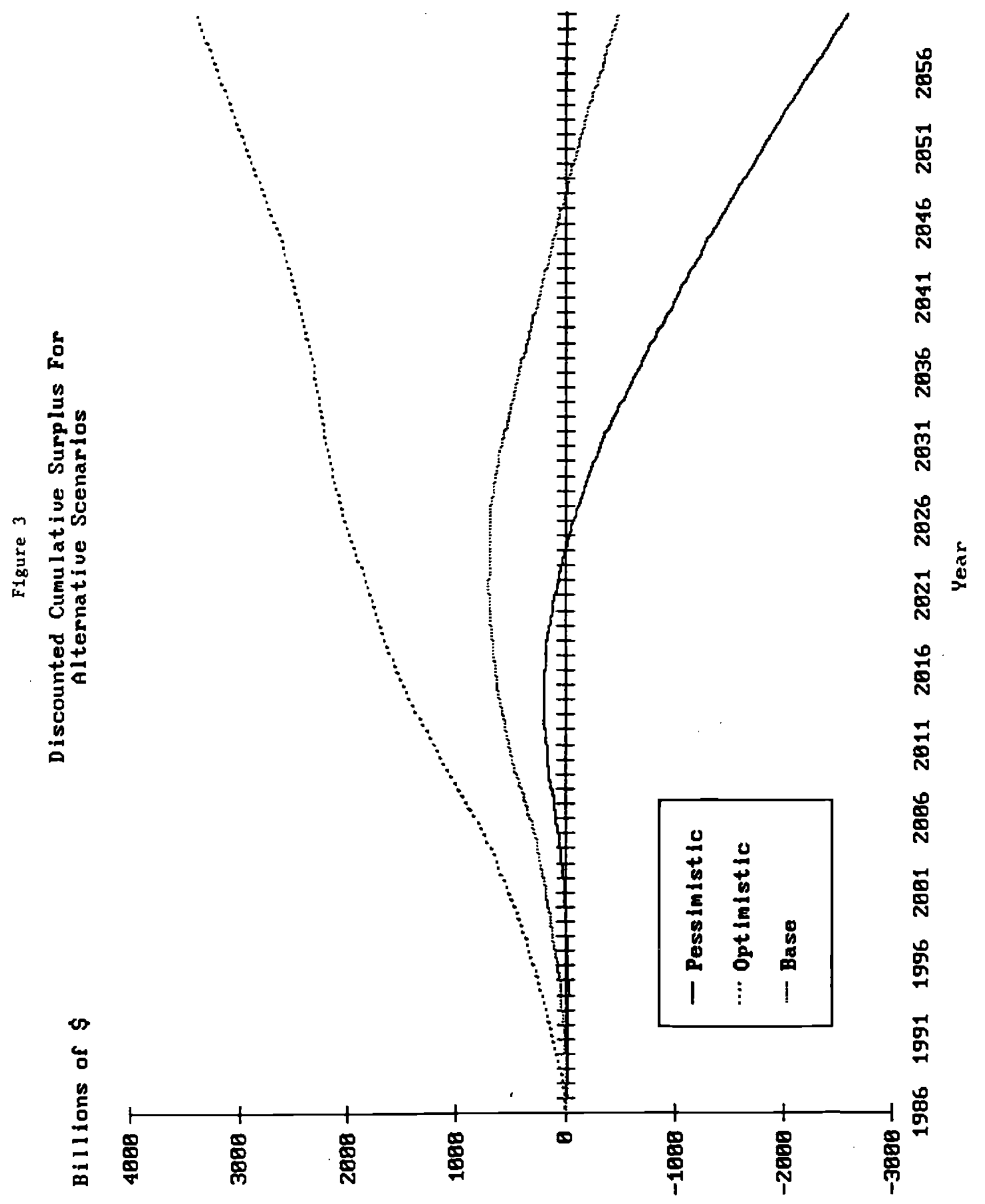




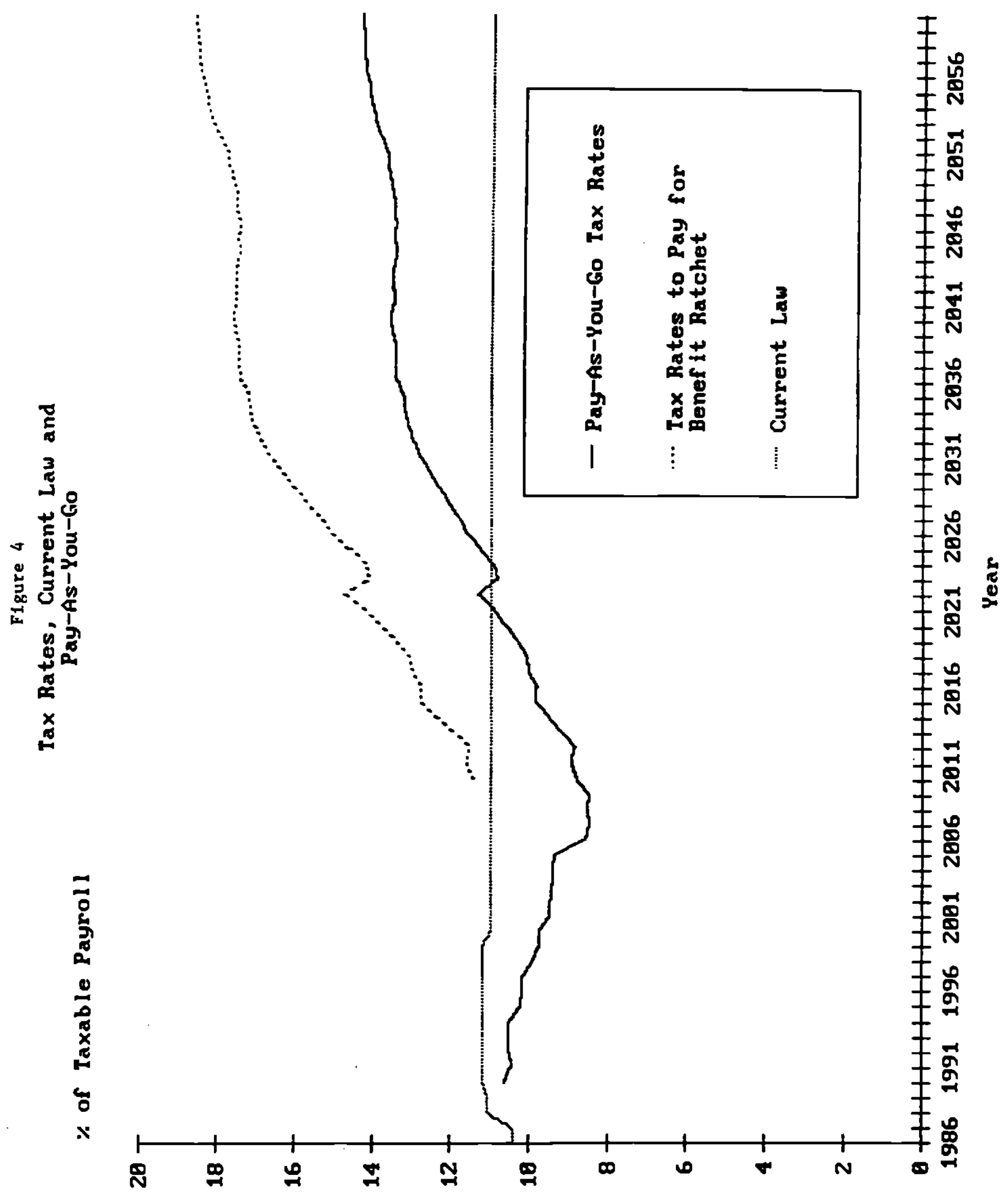




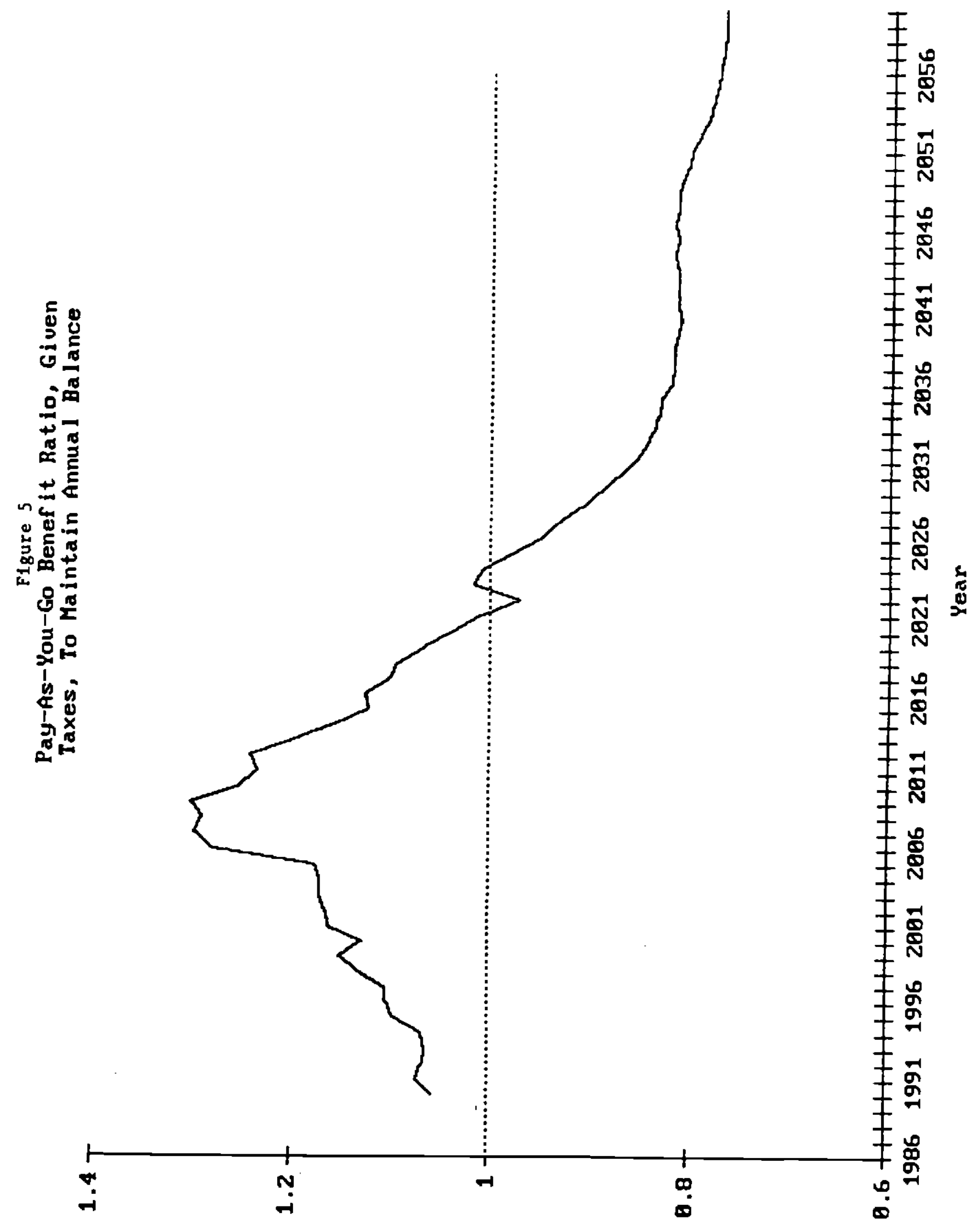


Table 1

Base Case (Intermediate Assumption)

A. FINANCIAL FLOWS OF OASI TRUST FUND

1986 \$BILLIONS, DISCOUNTED TO 1986

$\begin{array}{llrrrrrrr}\text { TIME } & \text { PERIOD } & \text { PAYROLL } & \text { TAXES } & \text { BENEFITS } & \text { BEN TAXES } & \text { SURPLUS } & \begin{array}{l}\text { SURPLUS/ } \\ \text { PAYROLL }\end{array} \\ 1986 \text { TO 2010 } & 39584 & 4366 & 3997 & 114 & (141) & 483 & 1.228 \\ 2011 \text { TO 2035 } & 38540 & 4232 & 4422 & 158 & (198) & -31 & -0.08 \% \\ 2036 \text { TO 2060 } & 34460 & 3784 & 4925 & 196 & (244) & -946 & -2.748 \\ 1986 \text { TO 2060 } & 112584 & 12381 & 13344 & 468 & (584) & -495 & -0.448\end{array}$

B. FINANCIAL PATTERNS FOR BIRTH-YEAR COHORTS

1986 \$BILLIONS, DISCOUNTED TO 1986

\begin{tabular}{|c|c|c|c|c|c|c|}
\hline Year of & Birth & $\begin{array}{l}\text { RETIREE } \\
\text { TAXES }^{b}\end{array}$ & $\begin{array}{c}\text { NET } \\
\text { BENEFITS }\end{array}$ & TRANSFER & $\begin{array}{l}\text { NONSURVIVOR } \\
\text { TAXES }\end{array}$ & $\begin{array}{l}\text { REAL RATE } \\
\text { OF RETURN }\end{array}$ \\
\hline BEFORE & 1912 & 385 & 3671 & 3286 & 186 & 11.618 \\
\hline 1913 TO & 1922 & 489 & 1582 & 1093 & 121 & 5.748 \\
\hline 1923 TO & 1932 & 776 & 1508 & 732 & 149 & 3.728 \\
\hline 1933 To & 1942 & 952 & 1446 & 495 & 193 & 2.758 \\
\hline 1943 Tо & 1952 & 1378 & 1695 & 316 & 340 & 1.968 \\
\hline 1953 Tо & 1962 & 1525 & 2040 & 515 & 350 & 2.318 \\
\hline 1963 TO & 1972 & 1414 & 1809 & 395 & 325 & 2.178 \\
\hline 1973 To & 1982 & 1287 & 1660 & 373 & 283 & 2.228 \\
\hline 1983 To & 1992 & 1337 & 1751 & 413 & 282 & $2.28 \%$ \\
\hline
\end{tabular}

C. EXPECTED VALUES FOR MIDDLE-INCOME SINGLE-EARNER COUPLES (1986 dollars, discounted to 1986)

\begin{tabular}{lrrrr} 
& \multicolumn{4}{c}{ Year of Birth of Couple } \\
\cline { 2 - 5 } & \multicolumn{1}{c}{1945} & 1960 & 1975 & \multicolumn{1}{c}{1990} \\
Present Value Benefits & 161,460 & 140,255 & 133,714 & 122,097 \\
Present Value Taxes & 144,950 & 149,825 & 139,859 & 128,581 \\
Present Value Transfer & 16,510 & $-9,570$ & $-6,145$ & $-6,484$ \\
Rate of Return & 2.348 & 1.808 & 1.878 & 1.858
\end{tabular}

Notes: a. Income taxation of benefits. Figures in parentheses refer to old tax law.

b. Payroll taxes pald by those who survive to collect benefits.

c. Benefits net of income taxation.

d. Payroll taxes pald by those who do not survive to collect benefits. 


\section{Financial Patterns for Various Typical Families - Base Case (Expected values in 1986 dollars, discounted at real rate of 28 )}

Family Earnings Level:

Division of Earnings:

$$
\frac{\text { Low }(\$ 10,000)}{1-0} \frac{\text { Middle }}{1 / 2-1 / 2} \frac{(\$ 30,000)}{1 / 2-1 / 2} \quad \frac{\text { High }(\$ 50,000)}{1-0} \frac{1 / 2-1 / 2}{1-0}
$$

I. 1945 Cohort

Discounting to 1970 :

Present Value Benefits Present Value Taxes

$\begin{array}{rrrr}65,455 & 52,881 & 117,616 & 96,723 \\ 37,015 & 36,171 & 105,589 & 108,514 \\ 28,440 & 16,710 & 12,027 & -11,791\end{array}$

$113,314119,920$

Present Value Transfers

36,171

12,027

$112,421 \quad 178,237$

$893-58,317$

Discounting to 1986 :

Present Value Benefits

Present Value Taxes

Present Value Transfers

$$
89,854
$$

50,813

72,594

161,460

49,655

144,950

132,778

148,965

39,041

22,939

16,510

$-16,187$

$\begin{array}{rr}155,554 & 164,624 \\ 154,329 & 244,679 \\ 1,225 & -80,055\end{array}$

Rate of Return

$3.73 \%$

3.17 웅

2.348

1.648

2.038

$0.75 \%$

II. 1960 Cohort

Discounting to 1985 :

Present Value Benefits

Present Value Taxes

Present Value Transfer

78,403

48,963

29,440

62,949

47,833

137,505

146,888

112,811

137,129

15,116

$-9,383$

143,499

170,004

141,828

Discounting to 1986 :

Present Value Benefits

Present Value Taxes

Present Value Transfer

79,971

49,942

30,029

64,207

48,790

140,255

15,417

$-9,570$

115,067

146,369

$-31,302$

$\begin{array}{ll}139,871 & 144,664 \\ 173,404 & 243,949 \\ -33,533 & -99,285\end{array}$

Rate of Return

$3.398 \quad 2.828$

1.808

1.27 요

$1.37 \%$

0.408 
cont. of Table 2

Financial Patterns for Various Typical Families - Base Case (Expected values in 1986 dollars, discounted at real rate of 28 )

Family Earnings Leve1:

Division of Earnings:

III. 1975 Cohort

Discounting to 2000:

Present Value Benefits

Present Value Taxes

Present Value Transfers

Discounting to 1986 :

Present Value Benefits

Present Value Taxes

Present Value Transfers

Rate of Return

IV. 1990 Cohort

Discounting to 2015:

Present Value Benefits

Present Value Taxes

Present Value Transfer

Discounting to 1986 :

Present Value Benefits

Present Value Taxes

Present Value Transfer

Rate of Return

$$
1-0 \frac{\text { Low }(\$ 10,000)}{1 / 2-1 / 2}
$$

$\frac{\text { Middle }(\$ 30,000)}{1-0}$

$\frac{\text { High }(\$ 50,000)}{1-0} \frac{1 / 2-1 / 2}{1 / 2}$

$\begin{array}{rrrrrr}96,616 & 77,388 & 176,432 & 144,978 & 175,842 & 182,174 \\ 61,614 & 60,078 & 184,540 & 180,232 & 214,567 & 300,387 \\ 35,102 & 17,310 & -8,108 & -35,254 & -38,725 & -118,213\end{array}$

73,224

46,620

58,651

45,532

26,604

13,119

$\begin{array}{rr}133,714 & 109,876 \\ 139,859 & 136,594 \\ -6,145 & -26,718\end{array}$

3.318

2.758

1.878

1.358
$133,267 \quad 138,066$
$162,616 \quad 227,657$
$-29,349 \quad-89,591$

$1.438 \quad 0.498$

123,218

76,112

47,106

98,859
74,285
24,574

216,823

228,337

$-11,514$

177,840
222,856
$-45,016$

221,189

, 261

$265,328 \quad 371,427$

$-44,139-142,166$

69,387

42,860

55,669

122,097
128,581
$-6,484$

100,145

125,495

41,832

$-25,350$

124,556

149,412

26,527

13,837

$-24,856-80,056$

3.408

2.848

1.858

1.338

1.4880 .558 


\begin{tabular}{|c|c|c|c|c|c|c|c|c|c|c|c|c|}
\hline & 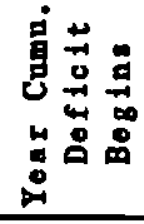 & $\underset{\sim}{\infty}$ & 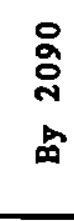 & $\underset{⿱ 丷}{\stackrel{n}{*}}$ & $\begin{array}{l}8 \\
\infty \\
0 \\
0 \\
\text { d }\end{array}$ & 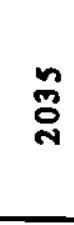 & 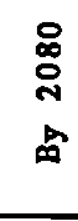 & 웅 & 홍 & 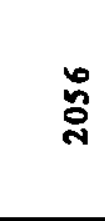 & - & స్ㅇㅁ \\
\hline 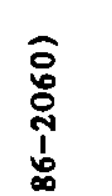 & 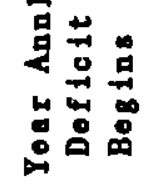 & ণ্ডি & 옹 & 옹 & స్ & $\underset{\sim}{\infty}$ & : & స્ડ & 勇 & స్ & - & স্ণ \\
\hline 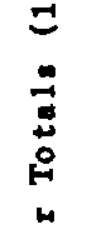 & 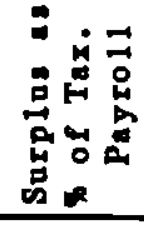 & $\frac{8}{8}$ & $\stackrel{n}{5}$ & $\begin{array}{l}\stackrel{0}{8} \\
i \\
i\end{array}$ & 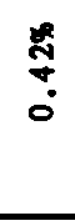 & $\frac{8}{i}$ & $\stackrel{8}{\stackrel{2}{7}}$ & $\underset{i}{\stackrel{2}{*}}$ & $\underset{8}{\stackrel{0}{\alpha}}$ & 渵 & $\frac{8}{\alpha}$ & $\begin{array}{l}\ddot{2} \\
\ddot{1}\end{array}$ \\
\hline $\begin{array}{l}0 \\
\cdots \\
\cdots \\
1 \\
0 \\
0 \\
0 \\
0 \\
0\end{array}$ & 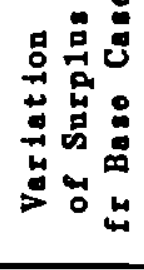 & 0 & $\begin{array}{l}m \\
m \\
+ \\
+\end{array}$ & $\underset{1}{\stackrel{D}{*}}$ & $\begin{array}{l}\stackrel{8}{8} \\
\stackrel{0}{+} \\
+\end{array}$ & $\begin{array}{l}n \\
\text { r } \\
\ddot{1} \\
\end{array}$ & 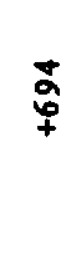 & $\underset{\infty}{\infty}$ & $\underset{⿱}{\stackrel{7}{0}}$ & $\begin{array}{l}\underset{\infty}{\infty} \\
\underset{+}{+}\end{array}$ & $\begin{array}{l}+ \\
\infty \\
\infty \\
\infty \\
+ \\
+\end{array}$ & 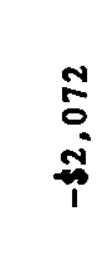 \\
\hline $\begin{array}{l}0 \\
0 \\
0 \\
0 \\
0 \\
0 \\
0 \\
0 \\
0 \\
0\end{array}$ & 点 & $\stackrel{n}{\stackrel{a}{+}}$ & $\underset{\infty}{\infty}$ & $\stackrel{\infty}{\stackrel{\infty}{+}}$ & $\underset{⿱ 亠 凶}{\infty}$ & $\frac{8}{7}$ & $\stackrel{a}{a}$ & $\begin{array}{l}N \\
2 \\
m \\
\ddot{n} \\
\ddot{1}\end{array}$ & $\underset{\infty}{\infty}$ & $\underset{i}{\stackrel{m}{F}}$ & $\underset{\infty}{\infty}$ & 官 \\
\hline 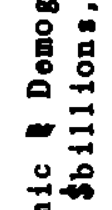 & 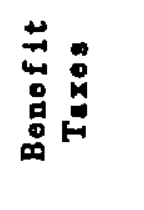 & 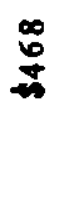 & 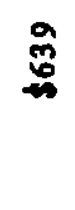 & $\underset{\infty}{\stackrel{\infty}{\infty}}$ & ్ㅜㅎ & $\underset{\mathscr{\Delta}}{\not}$ & ò & $\underset{+}{6}$ & $\underset{n}{\stackrel{n}{n}}$ & $\begin{array}{l}\tilde{0} \\
\ddot{\infty}\end{array}$ & $\underset{\infty}{\infty}$ & $\underset{+}{*}$ \\
\hline $\begin{array}{l}0.0 \\
0 \\
0 \\
0 \\
0 \\
0 \\
0 \\
0 \\
0 \\
0\end{array}$ & 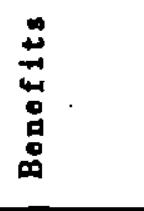 & $\underset{m}{m}$ & \begin{tabular}{l}
-1 \\
\hdashline \\
$\square$
\end{tabular} & $\begin{array}{l}0 \\
\ddot{n} \\
\ddot{n} \\
\Rightarrow\end{array}$ & 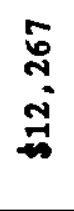 & $\underset{7}{\stackrel{7}{7}}$ & $\begin{array}{l}n \\
0 \\
m \\
m \\
m\end{array}$ & $\begin{array}{l}n \\
m \\
m \\
m \\
m \\
0\end{array}$ & $\frac{n}{a}$ & $\begin{array}{l}8 \\
\vdots \\
n \\
0 \\
-1\end{array}$ & $\begin{array}{l}0 \\
5 \\
0 \\
0 \\
-10\end{array}$ & 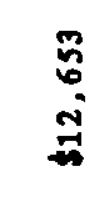 \\
\hline $\begin{array}{l}- \\
: \\
: \\
: \\
0 \\
0\end{array}$ & $\stackrel{0}{:}$ & 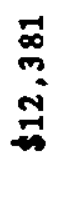 & $\begin{array}{l}\overrightarrow{1} \\
0 \\
\infty \\
\dot{\infty}\end{array}$ & $\begin{array}{l}0 \\
\square \\
0 \\
0 \\
01\end{array}$ & \begin{tabular}{l}
0 \\
0 \\
0 \\
\multirow{n}{*}{} \\
\multirow{2}{*}{}
\end{tabular} & 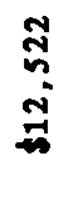 & $\begin{array}{l}a \\
a \\
0 \\
m \\
\infty\end{array}$ & $\begin{array}{l}0 \\
\ddot{n} \\
= \\
ت \\
=\end{array}$ & 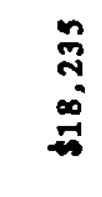 & 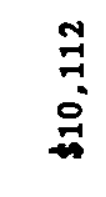 & $=$ & $\begin{array}{l}\frac{7}{b} \\
\dot{0}\end{array}$ \\
\hline के & $\begin{array}{l}0 \\
0 \\
0 \\
0 \\
0 \\
0 \\
0 \\
0\end{array}$ & $\begin{array}{l}: \\
0 \\
0 \\
: \\
0 \\
0 \\
0\end{array}$ & 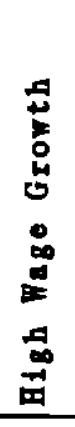 & 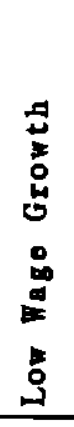 & 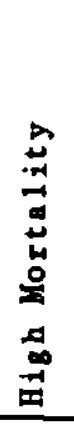 & 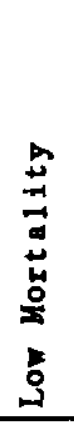 & 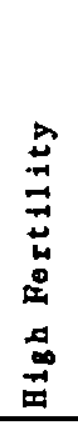 & 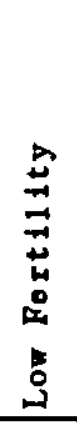 & 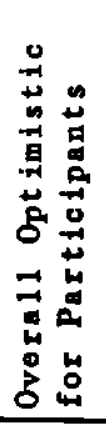 & 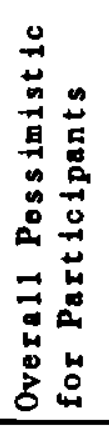 & 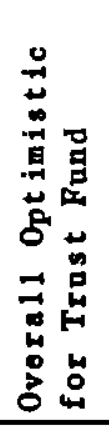 & 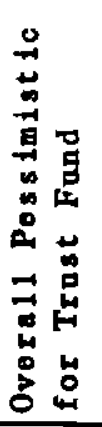 \\
\hline
\end{tabular}

 


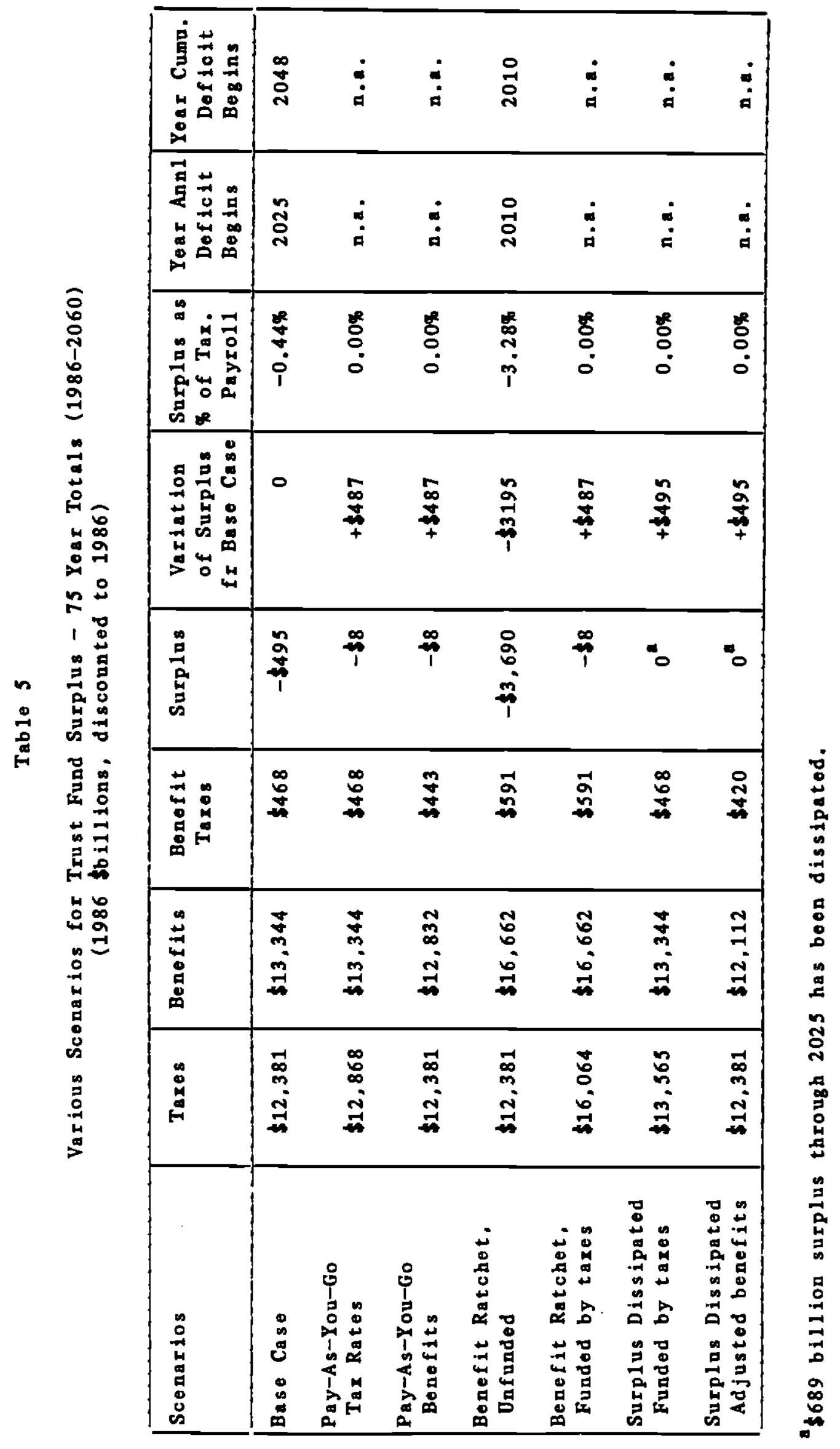




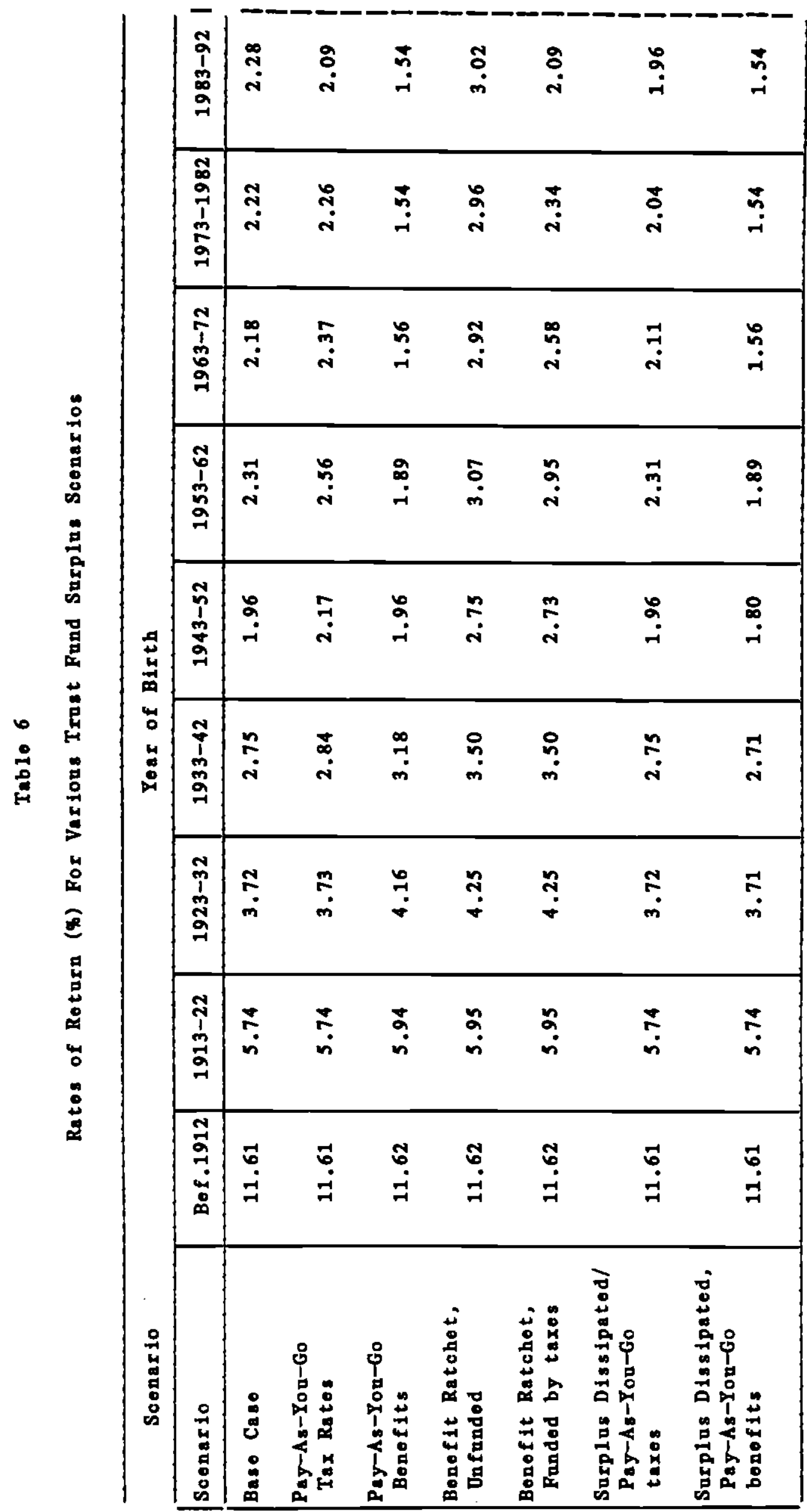


Table A.1

Overall Optimistic Scenario for Trust Fund

A. FINANCIAL FLOWS OF OASI TRUST FUND 1986 \$BILLIONS, DISCOUNTED TO 1986

$\begin{array}{llrrrrrr}\text { TIME } & \text { PERIOD } & \text { PAYROLL } & \text { TAXES } & \text { BENEFITS } & \text { BEN TAXES } & \text { SURPLUS } & \begin{array}{r}\text { SURPLUS } \\ \text { PAYROLI }\end{array} \\ 1986 \text { TO } 2010 & 44698 & 4930 & 3909 & 112 & 1133 & 2.548 \\ 2011 \text { TO 2035 } & 57150 & 6275 & 5328 & 191 & 1139 & 1.998 \\ 2036 \text { TO 2060 } & 72604 & 7972 & 7138 & 284 & 1117 & 1.548 \\ 1986 \text { TO } 2060 & 174452 & 19177 & 16376 & 587 & 3389 & 1.948\end{array}$

B. FINANCIAL PATTERNS FOR BIRTH-YEAR COHORTS 1986 \$BILLIONS, DISCOUNTED TO 1986

$\begin{array}{lrrrrr}\text { Year of Birth } & \begin{array}{r}\text { RETIREE } \\ \text { TAXES }^{b}\end{array} & \begin{array}{r}\text { NET } \\ \text { BENEFITS }^{c}\end{array} & \begin{array}{r}\text { NONSURVIVOR } \\ \text { TRANSFER }\end{array} & \begin{array}{r}\text { REAL RATE } \\ \text { TAXES }\end{array} \\ \text { OFEFORE RETURN } \\ 1913 \text { TO } 1912 & 389 & 3477 & 3087 & 180 & 11.508 \\ 1923 \text { TO } 1932 & 493 & 1497 & 1004 & 116 & 5.608 \\ 1933 \text { TO } 1942 & 750 & 1514 & 764 & 168 & 3.778 \\ 1943 \text { TO } 1952 & 963 & 1580 & 617 & 214 & 2.988 \\ 1953 \text { TO } 1962 & 1517 & 2001 & 484 & 377 & 2.188 \\ 1963 \text { TO } 1972 & 1716 & 2585 & 869 & 451 & 2.628 \\ 1973 \text { TO } 1982 & 1724 & 2498 & 774 & 462 & 2.478 \\ 1983 \text { TO } 1992 & 1730 & 2520 & 789 & 452 & 2.508 \\ \end{array}$

C. EXPECTED VALUES FOR MIDDLE-INCOME SINGLE-EARNER COUPLES (1986 dollars, discounted to 1986)

\begin{tabular}{rrrr}
\multicolumn{4}{c}{ Year of B1rth of Couple } \\
\multicolumn{1}{l}{1945} & 1960 & 1975 & 1990 \\
177,382 & 175,680 & 189,049 & 206,122 \\
153,492 & 176,518 & 190,083 & 202,926 \\
23,890 & -838 & $-1,034$ & 3,196 \\
2.488 & 1.988 & 1,988 & 2.058
\end{tabular}

Notes: a. Income taxation of beneflts.

b. Payroll taxes paid by those who survive to collect benefits.

c. Benefits net of income taxation.

d. Payroll taxes pald by those who do not survive to collect benefits. 


\section{Overall Pessimistic Scenario for Trust Fund}

A. FINANCIAL FLOWS OF OASI TRUST FUND 1986 \$BILIIONS, DISCOUNTED TO 1986

$\begin{array}{rlrrrrrr}\text { TIME } & \text { PERIOD } & \text { PAYROLI } & \text { TAXES } & \text { BENEFITS } & \text { BEN TAXES } & \text { SURPLUS } & \begin{array}{r}\text { SURPLUS } \\ \text { PAYROLL }\end{array} \\ 1986 \text { TO 2010 } & 36597 & 4036 & 3987 & 114 & 163 & 0.448 \\ 2011 \text { TO 2035 } & 30288 & 3326 & 4232 & 152 & -755 & -2.498 \\ 2036 \text { TO 2060 } & 20795 & 2283 & 4434 & 176 & -1975 & -9.508 \\ 1986 \text { TO 2060 } & 87679 & 9644 & 12653 & 441 & -2567 & -2.938\end{array}$

B. FINANCIAL PATTERNS FOR BIRTH-YEAR COHORTS 1986 \$BILIIONS, DISCOUNTED TO 1986

$\begin{array}{lrrrrr}\text { Year of Birth } & \begin{array}{r}\text { RETIREE }_{\text {TAXES }^{b}} \\ \text { BENEFITS }\end{array} & \begin{array}{r}\text { NET } \\ \text { TRANSFER }\end{array} & \begin{array}{r}\text { NONSURVIVOR } \\ \text { TAXES }\end{array} & \begin{array}{r}\text { REAL RATE } \\ \text { OF RETURN }\end{array} \\ \text { BEFORE } 1912 & 401 & 3729 & 3329 & 174 & 11.668 \\ 1913 \text { TO } 1922 & 522 & 1646 & 1123 & 103 & 5.78 \% \\ 1923 \text { TO } 1932 & 749 & 1509 & 759 & 175 & 3.698 \\ 1933 \text { TO } 1942 & 941 & 1400 & 458 & 179 & 2.70 \% \\ 1943 \text { TO } 1952 & 1423 & 1706 & 283 & 251 & 2.068 \\ 1953 \text { TO } 1962 & 1457 & 1924 & 466 & 264 & 2.378 \\ 1963 \text { TO } 1972 & 1303 & 1662 & 359 & 222 & 2.298 \\ 1973 \text { TO } 1982 & 1135 & 1474 & 338 & 175 & 2.378 \\ 1983 \text { TO } 1992 & 1073 & 1424 & 351 & 149 & 2.468\end{array}$

C. EXPECTED VALUES FOR MIDDLE-INCOME SINGLE-EARNER COUPLES (1986 dollars, discounted to 1986)

\begin{tabular}{rrrr}
\multicolumn{4}{c}{ Year of Birth of Couple } \\
\multicolumn{1}{l}{1945} & \multicolumn{1}{c}{1960} & 1975 & \multicolumn{1}{l}{1990} \\
156,901 & 134,791 & 118,899 & 107,208 \\
139,419 & 135,729 & 117,675 & 100,761 \\
17,482 & -938 & 1,225 & 6,447 \\
2.368 & 1.988 & 2.038 & 2.178
\end{tabular}

Notes: a. Income taxation of benefits.

b. Payroll taxes paid by those who survive to collect benefits.

c. Benefits net of income taxation.

d. Payroll taxes pald by those who do not survive to collect benefits. 
Pay-As-You-Go Tax Rates

A. FINANCIAL FLOWS OF OASI TRUST FUND

1986 \$BILLIONS, DISCOUNTED TO 1986

$\begin{array}{rlrrrrrr}\text { TIME PERIOD } & \text { PAYROLI. } & \text { TAXES } & \text { BENEFITS } & \text { BEN TAXES } & \text { SURPLUS } & \begin{array}{r}\text { SURPLUS } \\ \text { PAYROLL }\end{array} \\ 1986 \text { TO 2010 } & 39584 & 3875 & 3997 & 114 & -8 & -0.028 \\ 2011 \text { TO 2035 } & 38540 & 4263 & 4422 & 158 & 0 & 0.008 \\ 2036 \text { TO 2060 } & 34460 & 4730 & 4925 & 196 & 0 & 0.008 \\ 1986 \text { TO 2060 } & 112584 & 12868 & 13344 & 468 & -8 & -0.018\end{array}$

B. FINANCIAL PATTERNS FOR BIRTH-YEAR COHORTS

1986 \$BILLIONS, DISCOUNTED TO 1986

\begin{tabular}{|c|c|c|c|c|c|c|}
\hline Year of & Birth & $\begin{array}{l}\text { RETIREE } \\
\text { TAXES }^{b}\end{array}$ & $\begin{array}{r}\text { NET } \\
\text { BENEFITS }\end{array}$ & TRANSFER & $\begin{array}{l}\text { NONSURVIVOR } \\
\text { TAXES }\end{array}$ & $\begin{array}{l}\text { REAL RATE } \\
\text { OF RETURN }\end{array}$ \\
\hline BEFORE & 1912 & 385 & 3671 & 3286 & 186 & 11.618 \\
\hline $1913 \mathrm{TO}$ & 1922 & 489 & 1582 & 1093 & 121 & 5.748 \\
\hline $1923 \mathrm{TO}$ & 1932 & 770 & 1508 & 739 & 149 & 3.738 \\
\hline $1933 \mathrm{TO}$ & 1942 & 917 & 1446 & 529 & 190 & 2.848 \\
\hline $1943 \mathrm{TO}$ & 1952 & 1277 & 1695 & 418 & 324 & 2.178 \\
\hline $1953 \mathrm{TO}$ & 1962 & 1398 & 2040 & 642 & 321 & 2.568 \\
\hline $1963 \mathrm{TO}$ & 1972 & 1332 & 1809 & 477 & 296 & 2.378 \\
\hline $1973 \mathrm{TO}$ & 1982 & 1284 & 1660 & 376 & 270 & 2.268 \\
\hline $1983 \mathrm{TO}$ & 1992 & 1441 & 1751 & 309 & 293 & 2.098 \\
\hline
\end{tabular}

C. EXPECTED VALUES FOR MIDDLE-INCOME SINGLE EARNER COUPLES (1986 dollars, discounted to 1986)

\begin{tabular}{llcc}
\multicolumn{4}{c}{ Year of Birth of Couple } \\
\hline 1945 & 1960 & 1975 & 1990 \\
$161,460^{*}$ & $140,255^{*}$ & $133,714^{*}$ & $122,097^{*}$ \\
135,689 & 136,580 & 136,663 & 143,260 \\
25,771 & 3,675 & $-2,947$ & $-21,163$ \\
2.538 & 2,088 & 1.938 & 1.518
\end{tabular}

Notes: a: Income taxation of benefits.

b: Payroll taxes paid by those who survive to collect benefits.

c: Benefits net of income taxation.

d: Payroll taxes paid by those who do not survive to collect benefits.

Same as Base Case. 
Table A.4

Pay-As-You-Go Benefits

A. FINANCIAL FLOWS OF OASI TRUST FUND

1986 \$BILLIONS, DISCOUNTED TO 1986

$\begin{array}{rlrrrrrr}\text { TIME } & \text { PERIOD } & \text { PAYROLL } & \text { TAXES } & \text { BENEFITS } & \text { BEN TAXES } & \text { SURPLUS } & \begin{array}{r}\text { SURPLUS } \\ \text { PAYROLL }\end{array} \\ 1986 \text { TO } 2010 & 39584 & 4366 & 4504 & 130 & -8 & -0.028 \\ 2011 \text { TO } 2035 & 38540 & 4232 & 4388 & 156 & 0 & 0.008 \\ 2036 \text { TO 2060 } & 34460 & 3784 & 3940 & 156 & 0 & 0.008 \\ 1986 \text { TO 2060 } & 112584 & 12381 & 12832 & 443 & -8 & -0.018\end{array}$

B. FINANCIAL PATTERNS FOR BIRTH-YEAR COHORTS

1986 \$BILLIONS, DISCOUNTED TO 1986

$\begin{array}{lccrrr}\text { Year of Birth } & \begin{array}{c}\text { RETIREE }_{\text {TAXES }^{b}} \\ \text { BENEFITS }\end{array} & \begin{array}{c}\text { NET } \\ \text { TRANSFER }\end{array} & \begin{array}{r}\text { NONSURVIVOR } \\ \text { TAXES }\end{array} & \begin{array}{r}\text { REAL RATE } \\ \text { OF RETURN }\end{array} \\ \text { BEFORE } 1912 & 385 & 3729 & 3344 & 186 & 11.628 \\ 1913 \text { TO } 1922 & 489 & 1702 & 1213 & 121 & 5.948 \\ 1923 \text { TO } 1932 & 776 & 1722 & 946 & 149 & 4.168 \\ 1933 \text { TO } 1942 & 952 & 1640 & 688 & 193 & 3.188 \\ 1943 \text { TO } 1952 & 1378 & 1696 & 317 & 340 & 1.968 \\ 1953 \text { TO 1962 } & 1525 & 1768 & 244 & 350 & 1.898 \\ 1963 \text { TO } 1972 & 1414 & 1463 & 49 & 325 & 1.568 \\ 1973 \text { TO } 1982 & 1287 & 1308 & 21 & 283 & 1.548 \\ 1983 \text { TO } 1992 & 1337 & 1348 & 11 & 282 & 1.548\end{array}$

C. EXPECTED VALUES FOR MIDDLE-INCOME SINGLE-EARNER COUPLES

(1986 dollars, discounted to 1986)

Year of Birth of Couple

\begin{tabular}{llll}
\hline 1945 & 1960 & 1975 & 1990
\end{tabular}

$\begin{array}{lcccr}\text { Present Value Benefits } & 167,542 * & 117,851 * & 106,195 * & 93,737 * \\ \text { Present Value Taxes } & 144,950^{*} & 149,825^{*} & 139,859^{*} & 128,581^{*} \\ \text { Present Value Transfer } & 22,592 & -31,974 & -33,664 & -34,844 \\ \text { Rate of Return } & 2.478 & 1.278 & 1.178 & 1.068\end{array}$

Notes: a: Income taxation of benefits.

b: Payroll taxes paid by those who survive to collect benefits.

c: Benefits net of income taxation.

d: Payroll taxes paid by those who do not survive to collect benefits.

Same as Base Case. 
Table A.5

Benefit Ratchet-Unfunded

A. FINANCIAL FLOWS OF OASI TRUST FUND 1986 \$BILLIONS, DISCOUNTED TO 1986

$\begin{array}{rlrrrrrr}\text { TIME } & \text { PERIOD } & \text { PAYROLL } & \text { TAXES } & \text { BENEFITS } & \text { BEN TAXES } & \text { SURPLUS } & \begin{array}{r}\text { SURPLUS } \\ \text { PAYROLL }\end{array} \\ 1986 \text { TO } 2010 & 39584 & 4366 & 4511 & 130 & -15 & -0.048 \\ 2011 \text { TO } 2035 & 38540 & 4232 & 5748 & 206 & -1311 & -3.408 \\ 2036 \text { TO 2060 } & 34460 & 3784 & 6403 & 254 & -2365 & -6.868 \\ 1986 \text { TO } 2060 & 112584 & 12381 & 16662 & 591 & -3690 & -3.288\end{array}$

B. FINANCIAL PATTERNS FOR BIRTH-YEAR COHORTS 1986 \$BILLIONS, DISCOUNTED TO 1986

$\begin{array}{lrrrrr}\text { Year of Birth } & \begin{array}{r}\text { RETIREE }_{\text {TAXES }^{b}} \\ \text { BENEFITS }\end{array} & \begin{array}{r}\text { NET } \\ \text { BENANSFER }^{\text {NONSURVIVOR }} \\ \text { TAXES }\end{array} & \begin{array}{r}\text { REAL RATE } \\ \text { OF RETURN }\end{array} \\ \text { BEFORE } 1912 & 385 & 3730 & 3346 & 186 & 11.628 \\ 1913 \text { TO } 1922 & 489 & 1713 & 1224 & 121 & 5.958 \\ 1923 \text { TO } 1932 & 776 & 1782 & 1006 & 149 & 4.258 \\ 1933 \text { TO } 1942 & 952 & 1840 & 889 & 193 & 3.508 \\ 1943 \text { TO } 1952 & 1378 & 2203 & 825 & 340 & 2.758 \\ 1953 \text { TO } 1962 & 1525 & 2652 & 1127 & 350 & 3.078 \\ 1963 \text { TO } 1972 & 1414 & 2351 & 937 & 325 & 2.928 \\ 1973 \text { TO } 1982 & 1287 & 2158 & 871 & 283 & 2.968 \\ 1983 \text { TO } 1992 & 1337 & 2276 & 939 & 282 & 3.028\end{array}$

Notes: a: Income taxation of benefits.

b: Payroll taxes paid by those who survive to collect benefits.

c: Benefits net of income taxation.

d: Payroll taxes paid by those who do not survive to collect benefits. 
Table A. 6

Benefit Ratchet, Funded by taxes

A. FINANCIAL FLOWS OF OASI TRUST FUND 1986 \$BILLIONS, DISCOUNTED TO 1986

$\begin{array}{rlrrrrrr}\text { TIME } & \text { PERIOD } & \text { PAYROLL } & \text { TAXES } & \text { BENEFITS } & \text { BEN TAXES } & \text { SURPLUS } & \begin{array}{r}\text { SURPLUS } \\ \text { PAYROLL }\end{array} \\ 1986 \text { TO 2010 } & 39584 & 4373 & 4511 & 130 & -8 & -0.028 \\ 2011 \text { TO 2035 } & 38540 & 5542 & 5748 & 206 & 0 & 0.008 \\ 2036 \text { TO 2060 } & 34460 & 6149 & 6403 & 254 & 0 & 0.008 \\ 1986 \text { TO } 2060 & 112584 & 16064 & 16662 & 591 & -8 & -0.018\end{array}$

B. FINANCIAL PATTERNS FOR BIRTH-YEAR COHORTS

1986 \$BILLIONS, DISCOUNTED TO 1986

Year of Birth

RETIREE

TAXES

NET
BENEFITS

TRANSFER

NONSURVIVOR $d$ REAL RATE

BEFORE 1912

1913 TO 1922

385

489

3730

1713

776

1782

1933 TO 1942

952

1943 TO 1952

1390

1840

1611

1953 TO 1962

1963 TO 1972

1622

1973 TO 1982

1983 TO 1992

1634

2203

2652

2351

2158

1871

2276

3346
1224
1006
889
813
1041
730
524
405

186

121

149

193

341

359

354

342

380

OF RETURN

C. EXPECTED VALUES FOR MIDDLE-INCOME SINGLE-EARNER COUPLES

(1986 dollars, discounted to 1986)

\begin{tabular}{rrrr}
\multicolumn{5}{c}{ Year of Birth of Couple } \\
\hline 1945 & \multicolumn{1}{l}{1960} & 1975 & 1990 \\
209,904 & 182,337 & 173,834 & 158,731 \\
145,058 & 159,960 & 173,405 & 186,244 \\
64,846 & 22,377 & 429 & $-27,513$ \\
3.168 & 2.408 & 2.018 & 1.518
\end{tabular}

Present Value Benefits

Present Value Taxes

Present Value Transfer

3.168

2.408

1.518

Notes: a: Income taxation of benefits.

b: Payroll taxes paid by those who survive to collect benefits.

c: Benefits net of income taxation.

d: Payroll taxes paid by those who do not survive to collect benefits. 
Table A.7

Surplus Dissipated, Funded by Tax Increase After 2025

A. FINANCIAL FLOWS OF OASI TRUST FUND

1986 \$BILLIONS, DISCOUNTED TO 1986

$\begin{array}{llrrrrrr}\text { TIME } & \text { PERIOD } & \text { PAYROLI } & \text { TAXES } & \text { BENEFITS } & \text { BEN TAXES } & \text { SURPLUS } & \begin{array}{r}\text { SURPLUS } \\ \text { PAYROLL }\end{array} \\ 1986 \text { TO } 2010 & 39584 & 4366 & 3997 & 114 & 483 & 1.228 \\ 2011 \text { TO 2035 } & 38540 & 4470 & 4422 & 158 & 206 & 0.548 \\ 2036 \text { TO 2060 } & 34460 & 4730 & 4925 & 196 & 0 & 0.008 \\ 1986 \text { TO 2060 } & 112584 & 13565 & 13344 & 468 & 689 & 0.618\end{array}$

B. FINANCIAL PATTERNS FOR BIRTH-YEAR COHORTS

1986 \$BILIIONS, DISCOUNTED TO 1986

\begin{tabular}{|c|c|c|c|c|c|c|}
\hline \multirow{2}{*}{ Year of } & \multirow{2}{*}{ Birth } & \multirow{2}{*}{$\begin{array}{l}\text { RETIREE } \\
\text { TAXES }^{b}\end{array}$} & \multirow{2}{*}{$\begin{array}{c}\text { NET } \\
\text { BENEFITS }^{c}\end{array}$} & \multicolumn{2}{|c|}{ NONSURVIVOR } & \multirow{2}{*}{$\begin{array}{l}\text { REAL RATE } \\
\text { OF RETURN }\end{array}$} \\
\hline & & & & TRANSFER & TAXES & \\
\hline BEFORE & 1912 & 385 & 3671 & 3286 & 186 & 11.618 \\
\hline 1913 TO & 1922 & 489 & 1582 & 1093 & 121 & 5.748 \\
\hline $1923 \mathrm{TO}$ & 1932 & 776 & 1508 & 732 & 149 & 3.728 \\
\hline $1933 \mathrm{TO}$ & 1942 & 952 & 1446 & 495 & 193 & 2.758 \\
\hline $1943 \mathrm{TO}$ & 1952 & 1378 & 1695 & 316 & 340 & 1.968 \\
\hline 1953 TO & 1962 & 1527 & 204.0 & 513 & 350 & 2.318 \\
\hline $1963 \mathrm{TO}$ & 1972 & 1450 & 1809 & 359 & 328 & 2.118 \\
\hline $1973 \mathrm{TO}$ & 1982 & 1378 & 1660 & 283 & 296 & 2.048 \\
\hline 1983 T0 & 1992 & 1500 & 1751 & 251 & 308 & 1.968 \\
\hline
\end{tabular}

C. EXPECTED VALUES FOR MIDDLE-INCOME SINGLE-EARNER COUPLES (1986 Dollars, discounted to 1986)

\begin{tabular}{llll}
\multicolumn{4}{c}{ Year of Birth of Couple } \\
\hline 1945 & 1960 & 1975 & 1990 \\
$161,460^{*}$ & $140,255^{*}$ & $133,714^{*}$ & $122,097^{*}$ \\
$144,950^{*}$ & 150,028 & 147,709 & 146,518 \\
$16,510^{*}$ & $-9,773$ & $-13,995$ & $-24,421$ \\
$2.348^{*}$ & 1.808 & 1.708 & 1.448
\end{tabular}

Present Value Benefits

Present Value Taxes

Present Value Transfer

Rate of Return

$$
2.348^{*} \quad 1.808
$$

$$
\begin{array}{r}
133,714^{\star} \\
147,709 \\
-13,995 \\
1.708
\end{array}
$$

1.448

Notes: a: Income taxation of benefits.

b: Payroll taxes paid by those who survive to collect benefits.

c: Benefits net of income taxation.

d: Payroll taxes paid by those who do not survive to collect benefits. Same as Base Case. 
Table A.8

Surplus Dissipated - Benefits Reduced After 2025

A. FINANCIAL FLOWS OF OASI TRUST FUND

1986 \$BILLIONS, DISCOUNTED TO 1986

$\begin{array}{rlrrrrrr}\text { TIME PERIOD } & \text { PAYROLI } & \text { TAXES } & \text { BENEFITS } & \text { BEN TAXES } & & \text { SURPLU } & \begin{array}{r}\text { SURPLUS } \\ \text { PAYROLL }\end{array} \\ 1986 \text { TO } 2010 & 39584 & 4366 & 3997 & 114 & 483 & 1.228 \\ 2011 \text { TO 2035 } & 38540 & 4232 & 4175 & 149 & 206 & 0.548 \\ 2036 \text { TO 2060 } & 34460 & 3784 & 3940 & 156 & 0 & 0.008 \\ 1986 \text { TO 2060 } & 112584 & 12381 & 12112 & 420 & 689 & 0.618\end{array}$

B. FINANCIAL PATTERNS FOR BIRTH-YEAR COHORTS 1986 \$BILLIONS, DISCOUNTED TO 1986

\begin{tabular}{lrrrrr} 
Year of Birth & $\begin{array}{r}\text { RETIREE } \\
\text { TAXES }^{b}\end{array}$ & $\begin{array}{r}\text { NET } \\
\text { BENEFITS }\end{array}$ & \multicolumn{2}{c}{ NONSURVIVOR $^{\text {TRANSFER }}$} & REAL RATE \\
TAXES & OF RETURN \\
BEFORE 1912 & 385 & 3671 & 3286 & & \\
1913 TO 1922 & 489 & 1582 & 1093 & 186 & 11.618 \\
1923 TO 1932 & 776 & 1506 & 730 & 149 & 5.748 \\
1933 TO 1942 & 952 & 1425 & 473 & 193 & 2.718 \\
1943 TO 1952 & 1378 & 1609 & 231 & 340 & 1.808 \\
1953 TO 1962 & 1525 & 1767 & 242 & 350 & 1.898 \\
1963 TO 1972 & 1414 & 1463 & 49 & 325 & 1.568 \\
1973 TO 1982 & 1287 & 1308 & 21 & 283 & 1.548 \\
1983 TO 1992 & 1337 & 1348 & 11 & 282 & 1.548
\end{tabular}

C. EXPECTED VALUES FOR MIDDLE-INCOME SINGLE-EARNER COUPLES (1986 Dollars, discounted to 1986)

\begin{tabular}{llll}
\multicolumn{4}{c}{ Year of Birth of Couple } \\
\hline 1945 & 1960 & 1975 & 1990
\end{tabular}

Present Value Benefits

$\begin{array}{cl}155,297 & 117,851 \\ 144,950^{\star} & 149,825^{\star} \\ 10,347 & -31,974\end{array}$

2.228

1.278

$$
\begin{aligned}
& 106,195 \\
& 139,859 \\
& -33,664
\end{aligned}
$$

1.17 \%
93,737
128,581

$-34,844$

1.068

Notes: a. Income taxation of benefits

b. Payroll taxes paid by those who survive to collect benefits.

c. Benefits net of income taxation.

d. Payroll taxes paid by those who do not survive to collect benefits.

Same as Base Case. 